\title{
Probing the high latitude ionosphere from ground-based observations: The state of current knowledge and capabilities during IPY (2007-2009)
}

\author{
Lucilla Alfonsi $^{\mathrm{a}, *}$, Andrew J. Kavanagh ${ }^{\mathrm{b}}$, Ermanno Amata ${ }^{\mathrm{c}}$, Pierre Cilliers ${ }^{\mathrm{d}}$, Emilia Correia ${ }^{\mathrm{e}, \mathrm{f}}$, \\ Mervyn Freeman $^{\mathrm{g}}$, Kirsti Kauristie ${ }^{\mathrm{h}}$, Ruiyuan Liu ${ }^{\mathrm{i}}$, Juha-Pekka Luntama ${ }^{\mathrm{h}}$, \\ Cathryn N. Mitchell ${ }^{\mathrm{j}}$, G.A. Zherebtsov ${ }^{\mathrm{k}}$
}

${ }^{\text {a } I s t i t u t o ~ N a z i o n a l e ~ d i ~ G e o f i s i c a ~ e ~ V u l c a n o l o g i a ~(I N G V), ~ V i a ~ d i ~ V i g n a ~ M u r a t a ~ 605, ~ R o m e, ~ I t a l y ~}$

b Space Plasma Environment and Radio Science Group, Department of Communication Systems, InfoLab 21, Lancaster University, Lancaster LA1 4WA, UK

${ }^{\mathrm{c}}$ Istituto di Fisica dello Spazio Interplanetario I.N.A.F., Via del fosso del cavaliere 100, 00133 Rome, Italy

${ }^{\mathrm{d}}$ Hermanus Magnetic Observatory (HMO), P.O. Box 32, Hermanus, South Africa

e Instituto Nacional de Pesquisas Espaciais (INPE), São José dos Campos, Brazil

f Centro de Rádio Astronomia e Astrofísica Mackenzie (CRAAM), Universidade Presbiteriana Mackenzie, Rua da Consolação 930, CEP: 01302-907 São Paulo, Brazil

${ }^{\mathrm{g}}$ British Antarctic Survey, High Cross Madingley Road, Cambridge, UK

h Finnish Meteorological Institute, Erik Palménin aukio 1, Helsinki, Finland

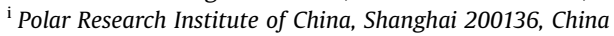

j Department of Electrical Engineering, University of Bath, Bath BA2 7AY, UK

${ }^{\mathrm{k}}$ Institute of Solar-Terrestrial Physics, Siberian Branch, Russian Academy of Science, Irkutsk, Russia

\section{A R T I C L E I N F O}

Article history:

Accepted 15 June 2008

Available online 2 July 2008

\section{Keywords:}

Polar ionosphere

International polar year

Conjugacy

Interhemispheric studies

\begin{abstract}
A B S T R A C T
During the International Polar Year (IPY), one area of great interest is co-coordinated, multi-instrument probing of the ionosphere at high latitudes. This region is important not only for the applications that rely upon our understanding of it, but also because it contains the footprints of processes that have their origin in the interplanetary space. Many different techniques are now available for probing the ionosphere, from radar measurements to the analysis of very low frequency (VLF) wave paths. Combining these methods provides the ability to study the ionosphere from high in the F-region to the bottom of the D-layer. Thus, coupling processes from the magnetosphere and to the neutral atmosphere can be considered. An additional dimension is through comparisons of the response of the two polar ionospheres to similar (or the same) geomagnetic activity. With more instruments available at the South Pole inter-hemispheric, studies have become easier to accomplish such that a fuller picture of the global response to Sun-Earth coupling can be painted.

This paper presents a review of the current state of knowledge in ionospheric probing. It cannot provide a comprehensive guide of the work to date due to the scale of the topic. Rather it is intended to give an overview of the techniques and recent results from some of the instruments and facilities that are a part of the IPY cluster 63-Heliosphere Impact on Geospace. In this way it is hoped that the reader will gain a flavor of the recent research performed in this area and the potential for continuing collaboration and capabilities during the IPY (2007-2009).
\end{abstract}

(c) 2008 Elsevier Ltd. All rights reserved.

\footnotetext{
* Corresponding author. Tel.: +3906 51860524; fax: +390651860397.

E-mail address: lucilla.alfonsi@ingv.it (L. Alfonsi).
}

\section{Introduction}

The International Polar Year (IPY) is a large scientific programme that unites many disciplines in the study of 
the Arctic and Antarctic. Running from March 2007 to 2009 one of the principal goals is to perform coordinated, continuous and systematic monitoring of the polar regions as a means to understand the natural mechanisms that govern our planet. The IPY is the successor to similar initiatives held in 1882-1883, 1932-1933 and 1957-1958 with ambitious numbers: over 200 projects with thousands of scientists from more than 60 nations dealing with physical, biological and social research proposals. This is facilitated by taking advantage of the development of internet technology, which enables the sharing of expertise, data and facilities. Whereas the International Geophysical Year (IGY, 1957-1958) focused on monitoring geophysical processes the IPY enlarges the concept to all scientific and social disciplines related to the polar regions, highlighting the spirit of collaboration and the important heritage left by the IGY.

During the IGY ionospheric science assumed a prominent role, leading to the inauguration of several permanent observatories and actively contributing to the collection of measurements at the World Data Centers (WDCs). Since then ionospheric science has continued to provide interesting results and applications, and the polar ionosphere offers a unique environment for research. At latitudes poleward of the auroral oval the geomagnetic field lines that thread the ionosphere connect directly with interplanetary space (Dungey, 1961). This offers a unique laboratory for studying large-scale plasma processes at close quarters. Natural perturbations in the solarterrestrial environment can propagate from high to middle latitudes and may seriously degrade or affect technological systems relying on ionospheric and trans-ionospheric radio propagation. The reliability of some of these systems is vital for safety-of-life applications. Consequently, upper atmosphere monitoring from ground-based stations is required to investigate and model ionospheric variability and to subsequently optimise forecasting techniques.

One of the core projects of the IPY is "Heliosphere Impact on Geospace". This consists of 29 individual programmes that have been brought together and defined as cluster 63 by the IPY Project Office. Interhemispheric Conjugacy Effects in Solar-Terrestrial and Aeronomy Research (ICESTAR, endorsed and funded by the Scientific Committee on Antarctic Research, SCAR) and International Heliophysical Year (IHY) are the two principal programmes that have been identified to lead the cluster providing management responsibilities and serving as the contact point with the central IPY coordination. The countries involved in the project are: Australia, Brazil, Canada, China, Finland, Italy, Japan, Malaysia, Norway, Poland, Russia, South Africa, Sweden, UK, Ukraine and USA. The cluster has three main themes that reflect the diverse research aims of the individual contributors:

- Coupling processes between the different atmospheric layers and their connection with solar activity.

- Energy and mass exchange between the ionosphere and the magnetosphere.

- Inter-hemispheric similarities and asymmetries in geospace phenomena.
Each project in the cluster has a set of project-specific scientific objectives, but the interrelationships between the studied processes mean there is significant synergy between the projects. The result is that the cluster is able to address topics with far-reaching scientific impact and which are of import to society at large. For example, a practical benefit will be improved prediction of space weather phenomena, which adversely affect spacecraft operations, humans in space, and satellite-based positioning systems; on the scientific side, global-scale coordination of observing networks allows us to study conjugate and multi-scale geospace phenomena in fundamentally new ways.

With the start of the IPY a description of the state of knowledge of the polar ionosphere is timely. Here we provide a brief discussion on recent advances in highlatitude ionospheric science and describe the current capabilities for probing the ionosphere present in the IPY cluster 63. This covers observing, monitoring, and modelling the high latitude ionosphere, primarily using groundbased techniques limited to radio wave methods. The list of authors reflects those involved in such endeavours and does not comprehensively cover all aspects of the contributions to IPY cluster 63 science, which is beyond the scope of this article.

\section{Observations}

The ionised atmosphere over the auroral and polar regions is complex and dynamic. Consequently it takes a synergistic interpretation of a variety of observations and experimental techniques to properly characterise the ionospheric plasma conditions. The first goal of every IPY activity is to enhance the exchange of expertise to neighbouring fields. In this section, we provide an overview of the instruments and techniques that are already contributing to a coordinated probing of the ionosphere.

\subsection{Global Navigation Satellite System (GNSS) receivers}

Total electron content (TEC) is defined as the line integral of the electron concentration along a path from a satellite to a receiver. TEC can be measured using Faraday rotation or differential Doppler techniques. Since the availability of Global Navigation Satellite System (GNSS) satellites, starting from the early 1990s, phase delay and pseudo-range measurements from a significant number of ground stations became available for research. These measurements furnish TEC evaluation along large numbers of ray-paths. Dual frequency radio signals (L1: $1.6 \mathrm{GHz}$ and $\mathrm{L} 2: 1.2 \mathrm{GHz}$ ) that propagate through the ionosphere are subject to a differential phase change due to the dispersive nature of the plasma. As a first-order approximation the differential phase shift is directly proportional to the TEC between the transmitter and receiver.

The scientific community can access the data compiled by the International GNSS Service (IGS), formerly the International GPS Service, through the IGS web page (http://igscb.jpl.nasa.gov/). This is a voluntary consortium 
of more than 200 worldwide agencies that pool resources and data from permanent GPS \& GLONASS (Russia's Global Navigation Satellite System) receiver stations. Dense networks of ground-based GNSS receivers offer the potential to retrieve ionospheric electron density and TEC maps with unprecedented resolution. The highresolution TEC map over Scandinavia presented in Fig. 1 shows for the first time mesoscale features of the ionospheric plasma during a magnetic storm in the auroral region. This map was produced by the Finnish Meteorological Institute (FMI) and the University of Bath with data from the 86 fiducial GNSS stations in Finland (operated by Geotrim Ltd.) using the Multi-Instrument Data Analysis System (MIDAS, Mitchell and Spencer, 2003) algorithm.

Scintillation of satellite radio signals is caused by electron density irregularities, which distort the wavefront of a signal giving rise to a random amplitude and phase modulation of a wave (see Wernik et al., 2003). In order to study scintillation, which is highly transient, high rate receivers are required to detect and recognize the rapid phase and amplitude fluctuations on the GNSS signals. Scintillation measurements can be derived by means of receivers with a sampling rate up to $50 \mathrm{~Hz}$. Such systems have been adopted by several groups for both scientific purposes and space weather applications (De Franceschi et al., 2006). This twofold utilization arises from their capacity of providing amplitude and phase scintillation indices $\left(S_{4}, \sigma_{\Phi}\right)$ in real time, TEC and TEC phase (each logged every $15 \mathrm{~s}$ ) and in providing phase and amplitude data, either in raw form or detrended, at $50 \mathrm{~Hz}$ (Van Dierendonck et al., 1993). Examples of these measurements can be found by visiting the electronic space weather upper atmosphere (ESWUA) database: www.eswua.ingv.it (Romano et al., 2008). Such measurements are of crucial interest for testing irregularity and scintillation models, such as the one recently developed by Wernik et al. (2007).

Scintillation and/or TEC measurements are currently performed at auroral and polar latitudes of the Northern Hemisphere at: Ny Ålesund, Hornsund, Longyearbyen, Sodankylä, Oulu, Tromsø and at different sites over Canada (CANGIM network, Skone and Hoyle, 2005); and in Antarctica at: Zhongshan Station (China), MZS (Mario Zucchelli Station, Italy), Sanae IV Station (South Africa), Antarctic Research Station "Comandante Ferraz" (Estação Antártica Comandante Ferraz-EACF, Brazil). Information on the type of the receivers, on the starting time of observation, on the locations of the stations and on the managing institutions is reported in Table 1.

The Polar Research Institute of China (PRIC) manages two magnetically conjugate stations: Ny-Alesund (north) and Zhongshan (south) (Liu, 1998). They are located under the ionospheric projection of the magnetospheric cusp regions at noon and the polar cap regions at midnight, an ideal conjugate pair for monitoring solar wind-magnetosphere-ionosphere coupling processes.

Terrestrial dual-frequency GPS observations from the South African polar research vessel, the SA Agulhas, provides data on ionospheric variability in the South Atlantic and near the South Atlantic anomaly during its expeditions from South Africa to Antarctica, Marion Island and Gough Island (Cilliers et al., 2006). Data have been collected during all expeditions of the SA Agulhas since December 2005, and is used in the MIDAS algorithm for ionospheric tomography.

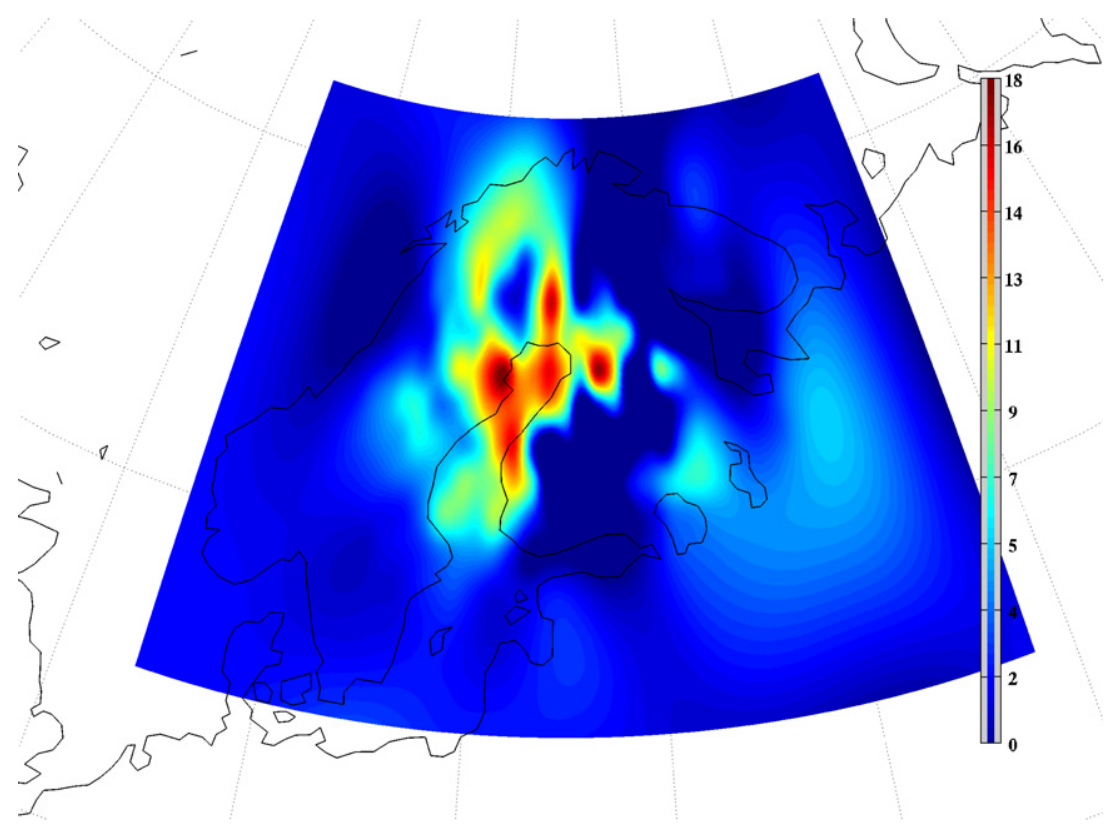

Fig. 1. High resolution TEC map on 15 December 2007 at 02:00 retrieved with the MIDAS algorithm (Luntama et al., 2007). The GPS observations used in the retrieval are from the 86 station GNSS network in Finland operated by Geotrim Ltd. The color bar shows the TEC values in TECU $\left(1 \mathrm{TECU}=10^{16}\right.$ electrons $\left./ \mathrm{m}^{2}\right)$. 
Table 1

High sampling rate time GNSS receivers at high latitudes

\begin{tabular}{|c|c|c|c|c|c|}
\hline Locations & Coordinates & Managing institutions & $\begin{array}{l}\text { Scintillations } \\
\text { (S) or TEC }\end{array}$ & $\begin{array}{l}\text { Starting } \\
\text { time-ending time }\end{array}$ & Receiver type \\
\hline Longyearbyen & $78.2^{\circ} \mathrm{N}, 15.6^{\circ} \mathrm{E}$ & INGV, romano@ingv.it & S+TEC & 2006- & GISTM (Novatel) \\
\hline Ny Ålesund & $78.1^{\circ} \mathrm{N}, 11.9^{\circ} \mathrm{E}$ & INGV, romano@ingv.it & S+TEC & 2003- & GISTM (Novatel) \\
\hline Ny Ålesund & $78.1^{\circ} \mathrm{N}, 11.9^{\circ} \mathrm{E}$ & Un.Wuhan, ryliu@pric.gov.cn & TEC & 2004- & Leica \\
\hline Hornsund & $77.0^{\circ} \mathrm{N}, 15.5^{\circ} \mathrm{E}$ & SRC-PAS, aww@cbk.waw.pl & S+TEC & 2007- & GISTM (Novatel) \\
\hline Hammerfest & $70.6^{\circ} \mathrm{N}, 23.8^{\circ} \mathrm{E}$ & $\begin{array}{l}\text { Un. Nottingham, } \\
\text { Marcio.Aquino@nottingham.ac.uk }\end{array}$ & $\mathrm{S}+\mathrm{TEC}$ & $2003-2004$ & GISTM (Novatel) \\
\hline Tromsø & $69.7^{\circ} \mathrm{N}, 19.0^{\circ} \mathrm{E}$ & CRIRP, crirp_zwm@163.com & $\mathrm{S}$ & $2004-$ & CJW-1 \\
\hline Tromsø & $69.7^{\circ} \mathrm{N}, 19.0^{\circ} \mathrm{E}$ & Un. Bath, c.n.mitchell@bath.ac.uk & $\mathrm{S}+\mathrm{TEC}$ & 2004-2006 & GISTM (Novatel) \\
\hline Kiruna & $67.5^{\circ} \mathrm{N}, 20.1^{\circ} \mathrm{E}$ & Un. Bath, c.n.mitchell@bath.ac.uk & S+TEC & 2004-2006 & Novatel \\
\hline Sodankylä & $67.4^{\circ} \mathrm{N}, 26.6^{\circ} \mathrm{E}$ & CRIRP, crirp_zwm@163.com & $\mathrm{S}$ & $2004-$ & CJW-1 \\
\hline Sodankylä & $67.4^{\circ} \mathrm{N}, 26.6^{\circ} \mathrm{E}$ & Un. Bath, c.n.mitchell@bath.ac.uk & S+TEC & 2004-2006 & GISTM (Novatel) \\
\hline Bronnoysund & $65.5^{\circ} \mathrm{N}, 12.1^{\circ} \mathrm{E}$ & $\begin{array}{l}\text { Un. Nottingham, } \\
\text { Marcio.Aquino@nottingham.ac.uk }\end{array}$ & S+TEC & 2003-2004 & GISTM (Novatel) \\
\hline Oulu & $63.9^{\circ} \mathrm{N}, 24.5^{\circ} \mathrm{E}$ & CRIRP, crirp_zwm@163.com & $\mathrm{S}$ & 2004- & CJW-1 \\
\hline Canada & $\begin{array}{l}62.5-51.1^{\circ} \mathrm{N} \\
246^{\circ} \mathrm{E}\end{array}$ & $\begin{array}{l}\text { Un. Calgary, } \\
\text { sskone@geomatics.ucalgary.ca }\end{array}$ & $\mathrm{S}+\mathrm{TEC}$ & 2003- & GISTM (Novatel) \\
\hline Bergen & $60.3^{\circ} \mathrm{N}, 5.3^{\circ} \mathrm{E}$ & $\begin{array}{l}\text { Un. Nottingham, } \\
\text { Marcio.Aquino@nottingham.ac.uk }\end{array}$ & S+TEC & $2003-2004$ & GISTM (Novatel) \\
\hline Marion Island & $46.9^{\circ} \mathrm{S}, 37.9^{\circ} \mathrm{E}$ & HMO, pjcilliers@hmo.ac.za & $\mathrm{S}+\mathrm{TEC}$ & 2007- & GISTM (Novatel) \\
\hline EACF & $62.1^{\circ} \mathrm{S}, 302^{\circ} \mathrm{E}$ & IBGE, ecorreia@craam.mackenzie.br & TEC & 2004- & Trimble+Javad \\
\hline Great Wall & $62.2^{\circ} \mathrm{S}, 301.0^{\circ} \mathrm{E}$ & Un. Wuhan, ryliu@pric.gov.cn & TEC & 1995- & Leica \\
\hline Zhongshan & $69.4^{\circ} \mathrm{S}, 76.4^{\circ} \mathrm{E}$ & CRIRP & S+TEC & 2000- & CJW-1 \\
\hline Zhongshan & $69.4^{\circ} \mathrm{S}, 76.4^{\circ} \mathrm{E}$ & Un. Wuhan, ryliu@pric.gov.cn & TEC & 1997- & Trimble+Leica \\
\hline SANAE IV & $71.7^{\circ} \mathrm{S}, 357.2 .0^{\circ} \mathrm{E}$ & HMO, pjcilliers@hmo.ac.za & S+TEC & 2006- & GISTM (Novatel) \\
\hline MZS & $74.7^{\circ} \mathrm{S}, 164.1^{\circ} \mathrm{E}$ & INGV, romano@ingv.it & S+TEC & 2006- & GISTM (Novatel) \\
\hline Dome C & $75.0^{\circ} \mathrm{S}, 123.0^{\circ} \mathrm{E}$ & INGV, romano@ingv.it & S+TEC & 2008- & GISTM (Novatel) \\
\hline
\end{tabular}

Acronymns: CRIRP: China Research Institute of Radiowave Propagation, IBGE: Brazilian Institute of Geography and Statistics, HMO: Hermanus Magnetic Observatory, INGV: Istituto Nazionale di Geofisica e Vulcanologia, SRC-PAS: Space Research Center-Polish Academy of Science.

\subsection{Vertical and oblique sounding}

Vertical sounding with ionosondes $(1-20 \mathrm{MHz}$ ) plays a crucial role in understanding the temporal and spatial evolution of the high-latitude ionosphere. The established nature of this technique allows the investigation of longterm trends (on decadal scales) that aid in study of the coupling between atmospheric layers. Studies such as this will shed light on the natural and anthropogenic-driven variations of the atmosphere and near-Earth space (Laštovicka, 2005). The echoes of the signal reflected by the ionosphere provide a profile of reflection frequency versus virtual height (the ionogram), which need to be inverted to give the electron density (directly related to the reflection frequency) profile as a function of actual height (Piggott and Rawer, 1972). Correct scaling of the returned data is difficult due to the lack of reliable models of the high-latitude ionosphere; several studies have compared different types of ionosonde (Romano et al., 2004; Morris et al, 2003), in an effort to improve scaling. Several different types of ionosondes are in use by various scientific communities such as the Digital Portable Sounder, DPS-4 (Haines and Reinisch, 1995), the KEL42 (Kelly, 1981), and the CADI (MacDougall, 1997) and a number of other ionosondes are in operation for IPY in both hemispheres.

In 2004, a new digital ionosonde, the AIS-INGV, was designed by Istituto Nazionale di Geofisica e Vulcanologia (INGV, Italy) (Zuccheretti et al., 2003) and deployed in Antarctica at MZS, giving encouraging results in terms of quality of data. A good quality ionogram is obtained by using the phase coherent integration, which improves the signal to noise ratio so that only well-defined echos are sketched (Fig. 2). This is of crucial importance when the information derived from the ionograms has to be provided for space weather purposes.

A DPS-4 was installed at Zhongshan Station during the austral summer 1994/1995. The DPS-4 has been in operation since February 1995, taking both ionograms and ionospheric drift measurements 8 times per hour. Ionospheric Prediction Service (IPS) acts as the Australian Space Weather Agency and manages several ionosondes located in Antarctica at Casey, Scott Base, Davis Mawson.

In the more accessible Arctic, the coverage of ionosondes is, obviously, richer, spanning from Canada, across Northern Europe, to Northern Asia. Institute of SolarTerrestrial Physics, Russian Academy of Science (ISTP RAS) manages a multi-position oblique sounder, with a receiver at v.Tory $\left(51.7^{\circ} \mathrm{N}, 103.1^{\circ} \mathrm{E}\right)$ and three transmitters located near Irkutsk $\left(52.9^{\circ} \mathrm{N}, 103.3^{\circ} \mathrm{E}\right)$, Norilsk $\left(69^{\circ} \mathrm{N}, 88^{\circ} \mathrm{E}\right)$ and Magadan $\left(60^{\circ} \mathrm{N}, 150.7^{\circ} \mathrm{E}\right)$. ISTP RAS in cooperation with Institute of Cosmophysical Research and Aeronomy (ICRA) and Institute of Cosmophysical Research and Radiowave Propagation (ICRRP) also manages a network of vertical ionosondes, which includes 8 sounders located at Norilsk $\left(69^{\circ} \mathrm{N}, 88^{\circ} \mathrm{E}\right)$, Tiksi $\left(71.58^{\circ} \mathrm{N}, 129.0^{\circ} \mathrm{E}\right)$, Zhigansk $\left(67.0^{\circ} \mathrm{N}\right.$, $\left.123.4^{\circ} \mathrm{E}\right)$, Yakutsk $\left(62.0^{\circ} \mathrm{N}, 129.6^{\circ} \mathrm{E}\right)$, Irkutsk $\left(52.4^{\circ} \mathrm{N}\right.$ $\left.104.3^{\circ} \mathrm{E}\right)$, Magadan $\left(60^{\circ} \mathrm{N}, 150.7^{\circ} \mathrm{E}\right)$, Petropavlovlovsk $\left(53^{\circ} \mathrm{N}, 158^{\circ} \mathrm{E}\right)$ and Khabarovsk $\left(48.5^{\circ} \mathrm{N}, 135.1^{\circ} \mathrm{E}\right)$. 


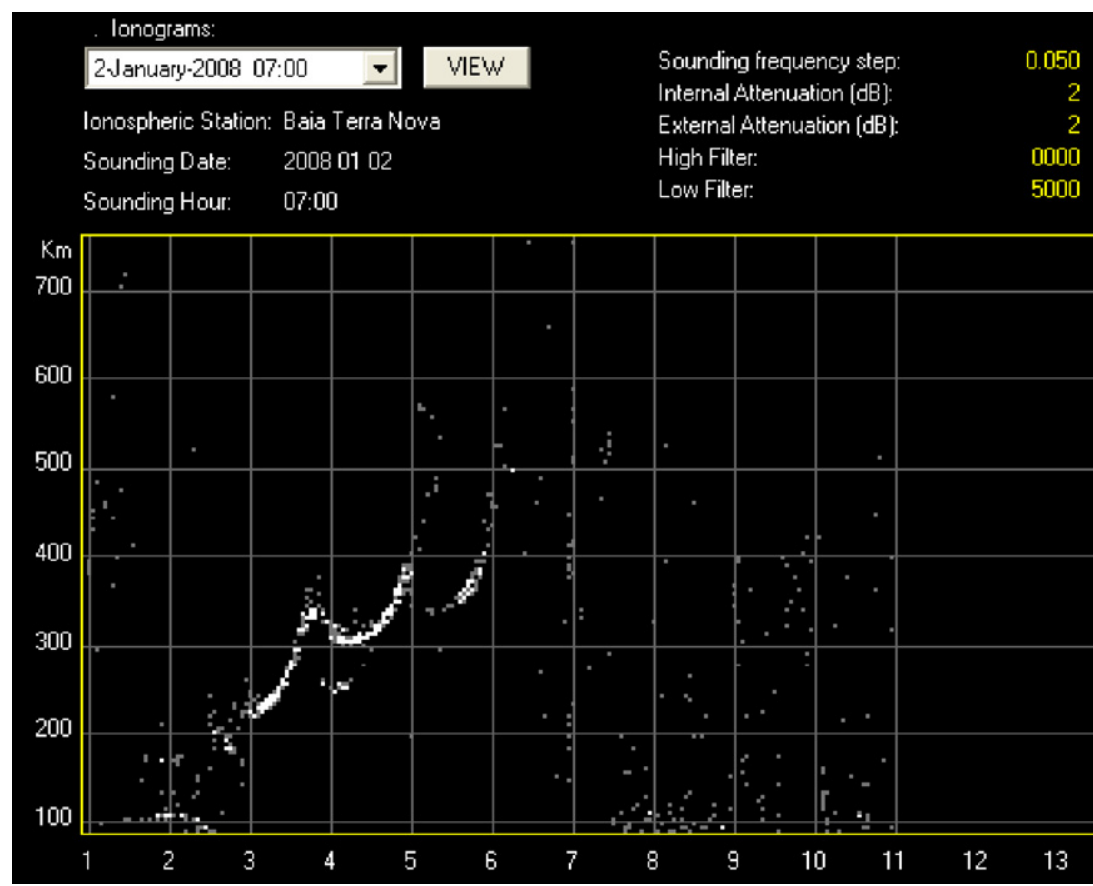

Fig. 2. Example of ionogram from AIS-INGV ionosonde at Mario Zucchelli Station (Antarctica).

\subsection{Riometers}

The relative ionospheric opacity meter (riometer) was devised in the late 1950s by Little and Leinbach (1959) and is essentially a sensitive, calibrated radio receiver. The riometer monitors the background cosmic radio noise at high frequencies (usually $20-50 \mathrm{MHz}$ ) received on the ground; by comparing the received signal with that for a geomagnetically undisturbed day it is possible to determine the attenuation of the radio waves and hence the cosmic radio noise absorption (CNA) at the monitored frequency. Most of this absorption occurs in the D-layer of the ionosphere where the electron-neutral collision frequency is high; in the auroral zone CNA is usually caused by the precipitation of electrons with energy in excess of $30 \mathrm{keV}$. CNA can also come from higher in the ionosphere from other effects such as increases in the E-region temperature, which raises collision frequency and so absorption (Stauning, 1984; Stauning and Olsen, 1989). In the polar ionosphere when convection is strong, heating events may be common leading to prolonged enhancements of CNA, possibly related to variations in the IMF $B_{Y}$ (Stauning, 1994) in the open polar cap. Patches of high F-layer electron density such as in the polar winter (Rosenberg et al., 1993; Wang et al., 1994) can produce measurable CNA during polar winter (low temperatures) and at low to mild geomagnetic activity. One of the most significant increases in radio absorption is produced by solar proton events that lead to polar cap absorption (Reid, 1974).

The first incarnation of the riometer consisted of a simple dipole antenna that received cosmic radio noise in a broad beam $\left(>60^{\circ}\right)$; although small spatial-scale details are lost (Rosenberg et al., 1991) this technique has proven to be a powerful method for probing the lower ionosphere. Initial discoveries utilizing this technique were documented by Hargreaves (1969). Narrow beam riometers have been used to probe small-scale features and the development of the imaging riometer (Detrick and Rosenberg, 1990) has allowed 2-D spatial maps of the lower ionosphere to be produced. The imaging riometer is a set of receivers that use a phased array of antennas to form a number of regularly spaced narrow beams, which measure CNA in various directions. Depending on the antennas and phasing, traditional imaging riometers exist with beam numbers from 16 to 256 though recent development have provided the capability for 716 pencil beams (Hagfors et al., 2003).

The Global Riometer Array (GLORIA) is an international collaborative programme involving 14 countries (at the last count) that currently operate over 50 riometers including 22 imaging systems, spread across both hemispheres. At the First International Riometer Workshop in Ambleside, England (23-27 August 2004), participants in GLORIA envisaged that ground-based and other remotesensing techniques will provide the ability to track the evolution of the high-energy electron population through the substorm cycle in both space and time. This is of particular importance during IPY/IHY 2007, since information about the energy of the precipitating electrons generated during substorms, how these electrons are accelerated and the source region of these electrons is severely limited. These electrons deposit energy in the D-layer and alter both the chemical reactions and the current systems in the ionosphere. Calculations of particle energies based on riometer absorption, and exploiting the high time resolution of the intended global monitoring 
of electron precipitation with the GLORIA network will provide important information on coupling processes with the atmosphere.

\subsection{Incoherent scatter radars}

The EISCAT incoherent scatter radar (ISR) system includes four antennas in the Fennoscandian mainland and two antennas in the Svalbard Archipelago. The mainland system includes transmitters both in VHF $(224 \mathrm{MHz})$ and UHF $(930 \mathrm{MHz})$ regimes, while both the Svalbard antennas operate in the VHF regime $(500 \mathrm{MHz})$. ISR measurements utilize weak backscatter from ionospheric electrons whose dynamics are controlled by ion acoustic waves. Comprehensive analysis of the spectrum of the backscattered signal yields estimates for the altitude profiles of ionospheric electron density, electron and ion temperatures and ion velocity along the antenna beam direction. With the tri-static UHF-system all three components of ion velocity can be measured, which makes EISCAT unique compared to the other existing ISR systems.

As EISCAT measures the ionospheric conditions in a wide altitude range (typically $80-500 \mathrm{~km}$ ) the system can support both geospace research and atmospheric coupling studies. In polar regions, auroral activity often obscures the signs of forcing that the ionosphere experiences from below due to tropospheric and mesospheric processes.

Comparison studies of space-based radio wave transmitter systems and EISCAT have now been conducted at least for 20 years. The role of EISCAT in these investigations has typically been to provide auxiliary data for validating the results of spaced-based observations. Among the first papers addressing this issue was the study by Kersley et al. (1988) who compared scintillation observations from the Navy Navigation Satellite System with EISCAT observations. They demonstrated a link between local electron density enhancements and scintillation events and associated the enhanced densities with ion temperature increases and plasma velocity shears. Soft electron precipitation was found to be a driver of the ionospheric conditions favoring scintillation. Jakowski et al. (1996) made one of the pioneering studies on relationships between GPS-signal propagation errors and features within EISCAT observations. This study discussed the opportunities to use EISCAT data to evaluate the transformation between slant and vertical TEC values.

At lower latitudes $\left(52.9^{\circ} \mathrm{N}, 103.3^{\circ} \mathrm{E}\right)$ the Irkutsk ISR is a monostatic, pulsed, frequency scan radar unit (Zherebtsov et al., 2002). The ISR consists of a double-section antenna system with antenna switch; transmitters; multichannel receiving system; radar control and signal-recording devices. The Irkutsk IS radar differs from similar systems due to its ability to emit and to receive only one linear field polarization. The returned signal fades in accordance with Faraday rotation of the electromagnetic wave polarization plane, thus makes it possible to define the profile of electron densities without the need for external calibration (e.g. using ionosondes) (Shpynev, 2003).

\subsection{SuperDARN network}

The SuperDARN network comprises of 12 HF radars in the Northern Hemisphere $(\mathrm{NH})$ and 7 radars in the Southern Hemisphere ( $\mathrm{SH}$ ), each consisting of a primary array of 16 antennae and an interferometer array of 4 antennae (Fig. 3; http://superdarn.jhuapl.edu).

Each radar is electronically steered into one of 16 different beam directions covering a fan of $52^{\circ}$. The radars transmit a short sequence of pulses, referred to as a multi-pulse sequence, and samples the returning echoes. Three parameters can then be determined: the backscattered power, spectral width and Doppler velocity of the plasma density irregularities in the ionosphere. In the standard operating mode, for each $3.25^{\circ}$ beam 75 spatial ranges are resolved with a $45 \mathrm{~km}$ separation (Greenwald et al., 1995; Chisham et al., 2007). The reconstruction of convection patterns using SuperDARN data is based on finding a functional form for the distribution of electrostatic potential in the ionosphere that best fits all the lineof-sight velocity measurements available at the time of interest (Ruohoniemi and Baker, 1998).

An example of such a reconstruction for the northern hemisphere is shown in Fig. 4, where the contours of constant electrostatic potential (solid and dashed lines) also represent flow streamlines and the black segments represent individual velocity vectors at MLT-MLAT cells where real SuperDARN measurements are present. Fig. 4 effectively images the global convection electric field, obtaining a result that is analogous to space-based images of the global distribution of auroral luminosity. To ensure that the solution is realistic over areas of sparse radar coverage, the velocity data are supplemented with data from the statistical model by Ruohoniemi and Greenwald (1996). The model data are selected according to the IMF orientation and magnitude at the magnetopause at the time of interest, which in turn are obtained through suitably time-lagged data from spacecraft situated in the solar wind. The model data are weighted in the fitting so that their impact on the solution is minimized. Improvements in the statistical model aspect of the convection mapping technique are continually under development and the continued expansion of the SuperDARN network reduces the reliance of the maps on the model data.

The coverage provided by the radars is sometimes sufficient to effectively determine the entire global convection pattern, i.e. the solution becomes independent of the selection of statistical model data. Global convection maps can be generated at the 1- or 2-min resolution of the radar scans, which is suitable for observing the response of ionospheric convection to changes in the solar wind and the IMF. Using internet links to many of the radars, a near-real-time mapping of the ionospheric convection pattern is now possible for the Northern Hemisphere and is displayed at the SuperDARN JHU/APL web site (http://superdarn.jhuapl.edu/). With the planned extension of the internet links to all of the Southern Hemisphere SuperDARN network, global convection mapping in both hemispheres is likely to become a routine SuperDARN data product. Limitations in the ability of the system to produce reliable convection maps exist due to a 

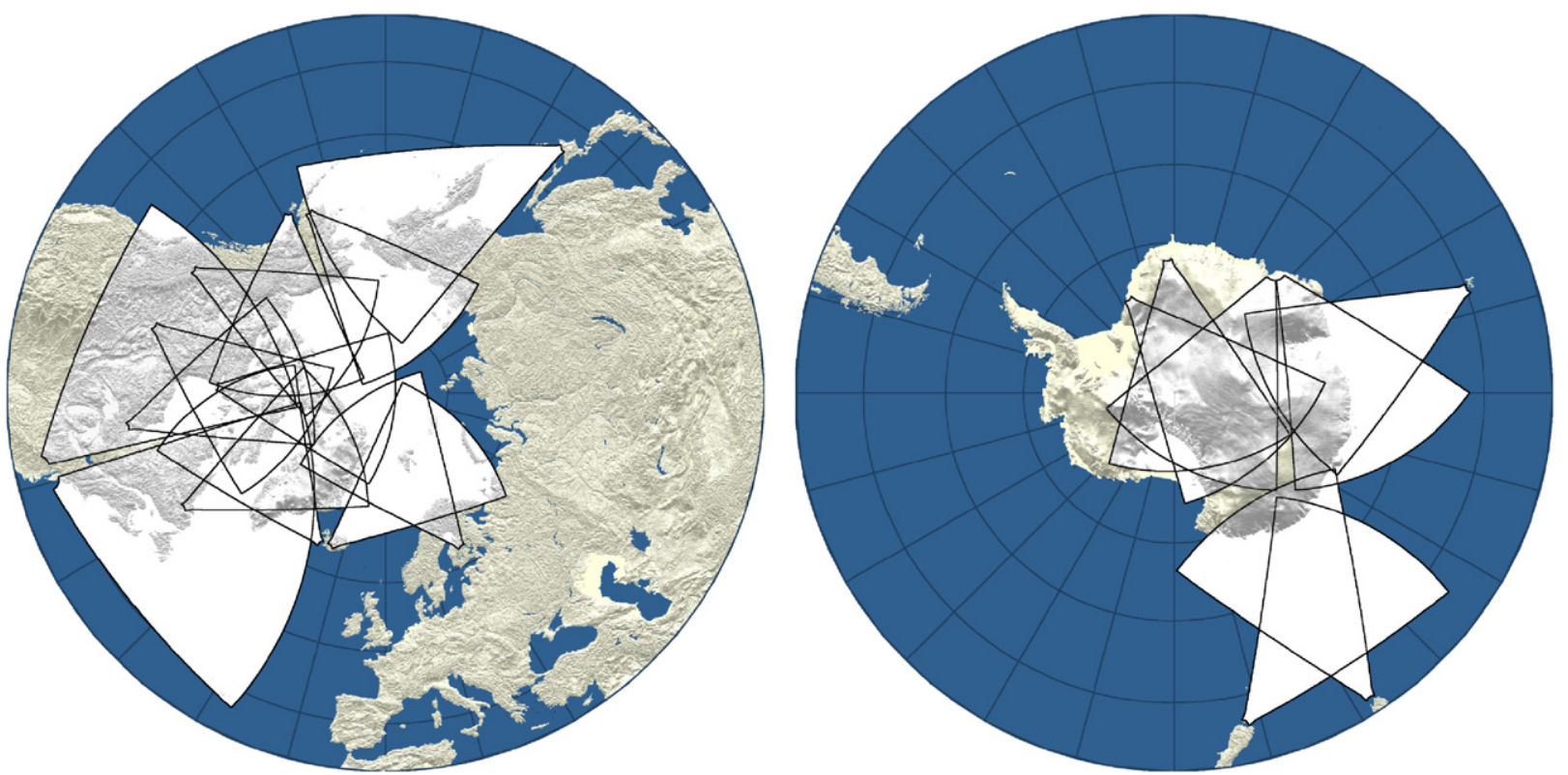

Fig. 3. Field of view plots of SuperDARN radars: northern hemisphere on the left, southern hemisphere on the right.
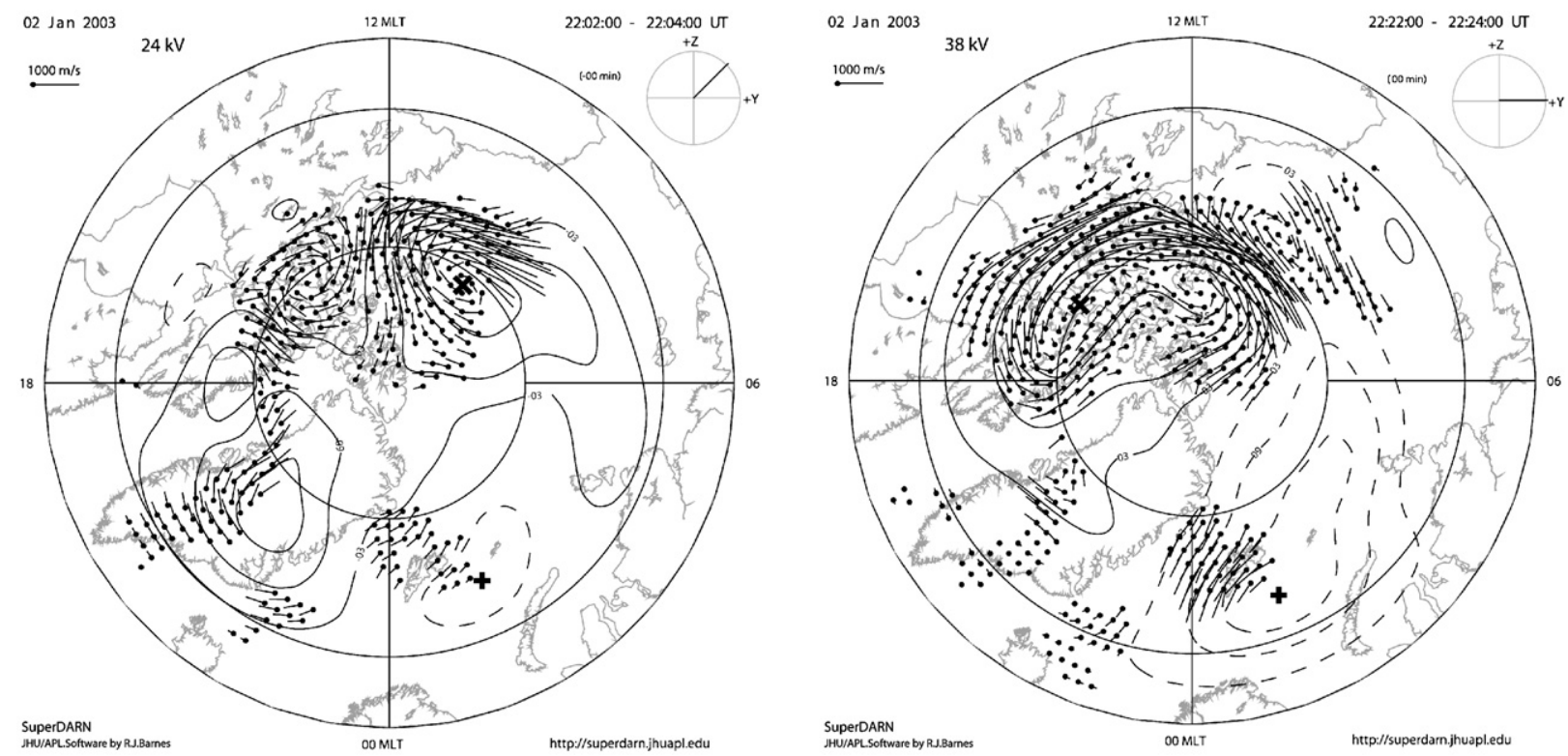

Fig. 4. Two SuperDARN MLT-MLAT polar plots showing northern hemisphere convection patterns for northward (left panel) and southward (right panel) IMF on 2 January 2003, both with $B_{y}>0$. Magnetic latitude goes from $65^{\circ}$ to $90^{\circ}$ MLAT, the two inner circles indicating $70^{\circ}$ and $80^{\circ}$ MLAT.

gap in the azimuthal coverage of the Northern Hemisphere high-latitude ionosphere over Siberia and to two similar gaps in the Southern Hemisphere coverage. However, from the end of 2008 the Southern Hemisphere gaps should be filled thanks to the installation of two radars at Dome $C$, while preparatory work has begun to fill the Northern Hemisphere gap through the installation of four Russian radars at three different locations in Siberia. Finally, three mid-latitude radars (having the larger fields of views in the left panel of Fig. 3) have been added to the original radars in the northern hemisphere. Such radars are mainly designed to extend the SuperDARN coverage to lower latitudes to follow the expansion of the auroral oval during storms and substorms.

\subsection{Very low frequency (VLF) sounding}

VLF radio waves can be used to study the variations in the lower ionosphere (D-layer). This region is maintained 
by the solar Lyman-alpha emission, but is highly disturbed by enhancements of X-ray emission during solar flares (McRae and Thomson, 2004; Raulin et al., 2006), and also by electron precipitation events from the radiation belts (Helliwell et al., 1973; Inan et al., 1982; Peter and Inan, 2004). These disturbances produce changes in the ionization rates, and consequently in the D-region parameters, conductivity gradient $\left(\beta-\mathrm{km}^{-1}\right)$ and reference height $\left(H^{\prime}-\mathrm{km}\right)$, which govern the refractive index (Wait and Spies, 1964). Thus VLF amplitude and phase are sensitive to changes in the electrical conductivity of the lower ionosphere, and can be used to probe ionospheric changes. Long data series are necessary to investigate the long-term trends of the ionosphere as a function of the solar cycle (McRae and Thomson, 2004; Pacini and Raulin, 2006; Raulin et al., 2006) and of its variations, which will complement the vertical and oblique sounding performed with HF radars.

VLF sounding is performed with signals at frequencies between 1 and $50 \mathrm{kHz}$, propagating over long distances inside the Earth-ionosphere waveguide. The most powerful transmitter stations are the US Navy communication Stations at Cutler/Maine (NAA at $24 \mathrm{kHz}, 44.65^{\circ} \mathrm{N}, 67.3^{\circ} \mathrm{W}$ ), Jim Creek/Washington (NLK at $24.8 \mathrm{kHz}, 48.2^{\circ} \mathrm{N}, 121.92^{\circ} \mathrm{W}$ ), Lualualei/Hawaii (NPM at $21.4 \mathrm{kHz}, 20.4^{\circ} \mathrm{N}, 158.2^{\circ} \mathrm{W}$ ), LaMoure/North Dakota (NLM at $25.2 \mathrm{kHz}, 46.35^{\circ} \mathrm{N}$, $98.33^{\circ} \mathrm{W}$ ) and Aquada/Puerto Rico (NAU at $40.75 \mathrm{kHz}$, $\left.18.4^{\circ} \mathrm{N}, 67.18^{\circ} \mathrm{W}\right)$.

The South America VLF Network (SAVNET) has receivers located at: Piura/Peru $\left(5.2^{\circ} \mathrm{S}, 80.5^{\circ} \mathrm{W}\right)$, Punta Lobos/Peru $\left(12.5^{\circ} \mathrm{S}, 76.8^{\circ} \mathrm{W}\right)$, Palmas/Brazil $\left(10.17^{\circ} \mathrm{S}, 49.34^{\circ} \mathrm{W}\right)$, Santa Maria/Brazil $\left(29.72^{\circ} \mathrm{S}, 53.72^{\circ} \mathrm{W}\right)$, CASLEO/Argentina $\left(31.5^{\circ} \mathrm{S}\right.$, $\left.68.5^{\circ} \mathrm{W}\right)$, São Paulo/Brazil $\left(23.2^{\circ} \mathrm{S}, 46.5^{\circ} \mathrm{W}\right)$ and at the Brazilian Antarctic Station, Comandante Ferraz $\left(62.1^{\circ} \mathrm{S}\right.$, $\left.58.4^{\circ} \mathrm{W}\right)$. Other participating Southern hemisphere VLF receivers, administered by the Hermanus Magnetic Observatory in cooperation with the University of Kwa-Zulu-Natal in South Africa are located on Marion Island $\left(46.88^{\circ} \mathrm{S}\right.$, $\left.37.86^{\circ} \mathrm{E}\right)$ and at SANAE-IV $\left(71.67^{\circ} \mathrm{S}, 2.84^{\circ} \mathrm{W}\right)$ in Antarctica.

\subsection{Multi-instrument studies}

The above-described instruments are typically used as combined assets in geospace research. Recent satellite missions, e.g. ESA's Cluster and NASA's Themis, count on substantial support from ground-based instrumentationmonitoring ionospheric phenomena simultaneously as the spacecraft probe different regions in the magnetotail. This combined diagnostic approach can provide a more powerful technique for analysing ionospheric phenomena.

\section{State of current knowledge and capabilities during IPY (2007-2009)}

\subsection{High-latitude convection patterns}

The large-scale morphology of ionospheric convection in the auroral and polar regions has been studied for many years using low-altitude spacecraft (Heppner and Maynard, 1987; Weimer, 1995) and ground magnetometers (Kamide et al., 1994; Papitashvili et al., 1994). More recently, SuperDARN convection measurements (Chisham et al., 2007, and references therein) have been used by Ruohoniemi and Greenwald $(1996,2005)$ to provide a complete picture of the statistical dependence of high-latitude convection on the IMF.

For a purely southward IMF, two high-latitude convection cells are set up in both hemispheres with antisunward flow in the polar cap and return flow from the night to the dayside at lower latitudes at dusk and dawn. The relative dimensions and orientations of the two cells depends on the magnetic clock angle $\theta$, defined as arctang $\left(B_{y} / B_{z}\right)$. For $\theta \sim 180^{\circ}$ two symmetric cells are observed, while for $\theta \sim 90^{\circ}$ the dusk and dawn cells dominate in the northern and in the southern hemisphere, respectively, and the opposite situation occurs when $\theta \sim-90^{\circ}$. As an example, the right-hand side of Fig. 4 (22.22-22.24 UT on 2 January 2003) shows a dayside northern convection dominated by a large and distorted clockwise cell extending from dusk over noon MLT to part of the dawn quadrant (for $B_{z}<0$ and $B_{y} \gg\left|B_{z}\right|$ ). For strongly northward IMF (i.e. for $\theta^{\prime} \approx 0^{\circ}$ ), reconnection occurs tailward of the cusps (lobe reconnection), thus generating two reverse cells, typically totally contained in the polar cap, often accompanied by two lower-latitude "viscous" cells at dusk (clockwise) and at dawn (counter-clockwise) to form a four cell pattern. The reverse cells display a high-latitude sunward flow and stir the open field lines within the polar cap itself (see the left panel of Fig. 4 , where $B_{z}>0$, at 22.02-22.04 UT on 2 January 2003), while a lobe-merging gap is located poleward with respect to the open closed field line boundary (OCB). If the IMF keeps pointing northward, the OCB may move poleward as magnetic flux is convected back to the day side.

The recent review by Chisham et al. (2007) provides an overview of the main scientific achievements obtained by the SuperDARN project (e.g. studies on FTE's, on gravity and planetary waves, on FAC's, etc.). Here, we will briefly discuss some very recent findings on dual-lobe reconnection, which was not included in that review.

Dual-lobe reconnection consists of the simultaneous reconnection of an IMF field line tailward of both the northern and the southern cusp, forming a newly closed field line on the day side, so that the reverse cells are no longer confined within the polar cap and the merging gap lies along the OCB. In such cases, the OCB is forced to move poleward very quickly in both hemispheres. Imber et al. (2006) first presented substantial evidence for the occurrence of dual-lobe reconnection during a period of strongly northward IMF; they identified two bursts of sunward plasma flow across the noon portion of the $\mathrm{OCB}$, indicating magnetic flux closure at the dayside. They also estimated that, in order for dual reconnection to occur, the interplanetary magnetic field clock angle must be within $10^{\circ}$ of the $z$-GSM-axis and that $2.5 \times 10^{30}$ solar wind protons were captured by the flux closure process, sufficient to populate the cold, dense plasma sheet observed following the dual-lobe reconnection interval. The same authors further pursued this topic in a second paper (Imber et al., 2007), while Marcucci et al. (2008) presented a detailed case study of SuperDARN, Cluster, DMSP and IMAGE FUV data for a period when the IMF was predominately northward with the $B_{y}$ component 
changing from positive to slightly negative and showed that, during $2 \mathrm{~h}$, four poleward movements of the OCB (associated with enhanced sunward/westward flows crossing the OCB itself) should be interpreted as the result of lobe flux re-closure occurring sporadically in the dusk sector. Moreover, for at least one such poleward movement, they noticed its coincidence with Cluster in situ observation of dual-lobe reconnection.

It is reasonable to assume that work on these topics will proceed during the IHY, taking advantage of the steadily increasing availability of SuperDARN data from both hemispheres. SuperDARN data provides two important space weather products: the high-latitude ionospheric convection pattern and the associated cross polar cap electric potential (CPCP) both in the northern and in the southern hemispheres. The study of interhemispheric effects regarding such products is a typical IPY task.

Ionospheric imaging can be used to obtain information on the temporal and spatial evolution of the electron density into the ionosphere (Bust and Mitchell, 2008). The understanding of the dynamics of the ionospheric plasma under perturbed conditions is crucial to comprehend the physical processes ruling the upper atmosphere when a storm occurs. Maps of the large-scale distribution of electron density can provide important information about ionospheric storm activity and progression. In the case of the famous Halloween storm on 30 October 2003, for instance, this type of reconstruction has shown the transportation of the plasma from North America towards Northern Europe in anti-sunward direction under the influence of convection flows in the high latitudes and, later, even towards mid latitudes in Europe (De Franceschi et al., 2008). A multi-instrument approach has allowed the identification of the convection of the plasma from the dayside ionosphere over the USA towards the nightside in Europe within polar-cap patches associated with GPS phase and amplitude scintillation at mid and high latitudes in Europe (Mitchell et al., 2005). A detailed study of the October and November 2003 storms, carried out with the synergistic adoption of ionospheric imaging (MIDAS technique), measurements from scintillations and TEC GPS receivers and model of electric potential in the polar cap (Weimer, 1995), has indicated a "stagnation" of plasma in the late UT time of 30 October (De Franceschi et al., 2008). Another example of the effectiveness of the multi-instrument approach is given in the paper by Coco et al. (2007), which demonstrates the potential of using scintillation and TEC observations to determine the information on the dynamics of the ionospheric irregularities during the storms derived from the SuperDARN reconstructions.

Modern ionosondes complement measurements from HF and IS radars by performing observations of the ionospheric drift, as in the case of the DPS-4 at Zhongshan Station. A statistical analysis on the observations made since 1995 has shown that ionospheric motion at cusp latitudes are mainly horizontal, in an average diurnal variation in good agreement with patterns from convection. Data analysis shows that the convection pattern is largely controlled by the azimuthal component of IMF
$B_{y}<0$, the horizontal velocities at 00MLT incline to the west and the entrance points towards the south are located between 7 and 8 MLT. When $B_{y}>0$, the horizontal velocities at 00 MLT incline to the east and the entrance points are located between 9 and 10 MLT. The convection patterns in the southern hemisphere mirror those in the northern hemisphere (Liu and Zhu, 1999).

\subsection{Electron density changes}

During the IGY (1957-1958) a number of permanent ionospheric observatories were set up across the World. At that time their role was crucial for planning HF radio links, especially for military use; but the increased capability in ionospheric sounding led to new discoveries in the nature of the plasma environment at high latitudes. Since then more than five solar cycles worth of data have been collected providing a valuable historical data set. This has proved useful in studies of atmospheric changes; for example, Ulich and Turunen (1997) used data from the Sodankylä ionosonde that suggested that the peak height of the local F2 layer decreased over a 39-year period. This would be consistent with model predictions (Bremer, 1992) of cooling of the lower thermosphere. More recently long series of historical data were analysed to investigate eventual trends in the long-term behaviour of the ionospheric electron density (Lastovicka et al., 2006) showing the sensitivity on the correction for solar activity. Since the auroral and polar ionosphere display complex variations the task of determining trends is particularly difficult at high latitudes. Studies in the southern hemisphere have also demonstrated a negative trend possibly indicative of thermospheric cooling (Alfonsi et al., 2001, 2002; Jarvis, 2001).

A statistical analysis of the monthly medians from 1995 to 2004 of the DPS-4 ionospheric sounder at Zhongshan Station (Antarctica) has revealed obvious diurnal and annual variations (Xu et al., 2006 and references therein; Fig. 5). There is a "magnetic noon anomaly" that fades at winter time and a semi-annual anomaly during solar maximum years. During the summer months, close to solar maximum vibrationally excited molecular nitrogen $\left(\mathrm{N}_{2}{ }^{*}\right)$ has a significant effect on the ionosphere. It increases the loss rate of the dominant ion $\mathrm{O}^{+}$, thereby reducing the electron concentration in the F region. At solar minimum the role played by by $\mathrm{N}_{2}{ }^{*}$ is much more limited.

An important feature in the ionosphere is the main ionospheric trough (MIT), which is the natural boundary between the mid-latitude and auroral ionosphere. Analysis of data from a meridian chain of ionosondes $\left(90^{\circ} \mathrm{E}\right)$ taken over the winter of 1982-1983 revealed important features of the dynamics of the MIT. Pirog et al. (1987) and Zherebtsov and Pirog (2001) performed a statistical analysis of anomalous and regular phenomena characteristic of subauroral and auroral latitudes. These investigations charted the development of ionospheric storms in a local time (LT) - Kp coordinate system and showed that the type of ionospheric disturbance poleward of the MIT depended on the station latitude, LT and level of geomagnetic activity. 
Comparing these results with more recent data suggests that the large-scale structure of the ionosphere, including the MIT moves towards mid-latitudes (Pirog et al., 2006; Zherebtsov et al., 2005).

During the afternoon, abrupt decreases of ionization in the F2-layer, known as the daytime trough, occur (Mendillo and Klobuchar, 2006). Studies using data from stations in Siberia and China have revealed that the afternoon trough is mainly observed at equinox and at mid-high-latitudes $(L>3)$ during the recovery phase of storms (Pirog et al., 2007). Recent calculations of electron density variations during afternoon troughs have been carried out to define a preliminary model. The model is based upon the numerical solution of a system of nonstationary equations that describe the balance of particles and thermal plasma energy within magnetic field tubes with base at $100 \mathrm{~km}$ altitude (Tashchilin and Romanova, 2002; Romanova, et al., 2006). Model calculations of electron density variations with evening observations of gradients in ionization support the assumption that the narrow and deep trough in the afternoon sector is formed by the belt of westward ionospheric drift with high velocities.

Combining techniques can provide greater insight into the ionospheric processes that occur in the Polar Regions. Lilensten and Cander (2003) have calibrated GPS-based TEC estimates with EISCAT observations and statistical ionosphere models and Stolle et al. (2004) used EISCAT data to evaluate electron density profiles as deduced with GPS radio occultation technique.

Ionospheric irregularities are usually confined into regions of enhanced electron concentration and their morphology can be effectively reconstructed with the use of observations from ionosondes, SuperDARN, EISCAT supported by models and imaging techniques. Since scintillation is directly related to the formation and transport of irregularities in the ionosphere, they can provide information on the variation of electron density. Typical scales of such irregularities are, at $\mathrm{L}$ band frequencies, of the order of hundreds of meters to kilometres and are common in the polar, auroral and equatorial ionosphere (see Wernik et al., 2003). At highlatitude the peak of scintillation often coincidence with severe TEC gradients as produced by the gradient drift instability, as recently demonstrated by high sample frequency receivers in the Arctic (Mitchell et al., 2005). Electron precipitation can also be responsible for scintillation on the satellite signals received at the ground (Smith et al., 2008). In this frame, the simultaneous measurement of TEC and scintillation contribute to the general monitoring of electron density changes in the F-region.

In the absence of daylight, the D-layer $(<90 \mathrm{~km}$ altitude) disappears during geomagnetically quiet periods.
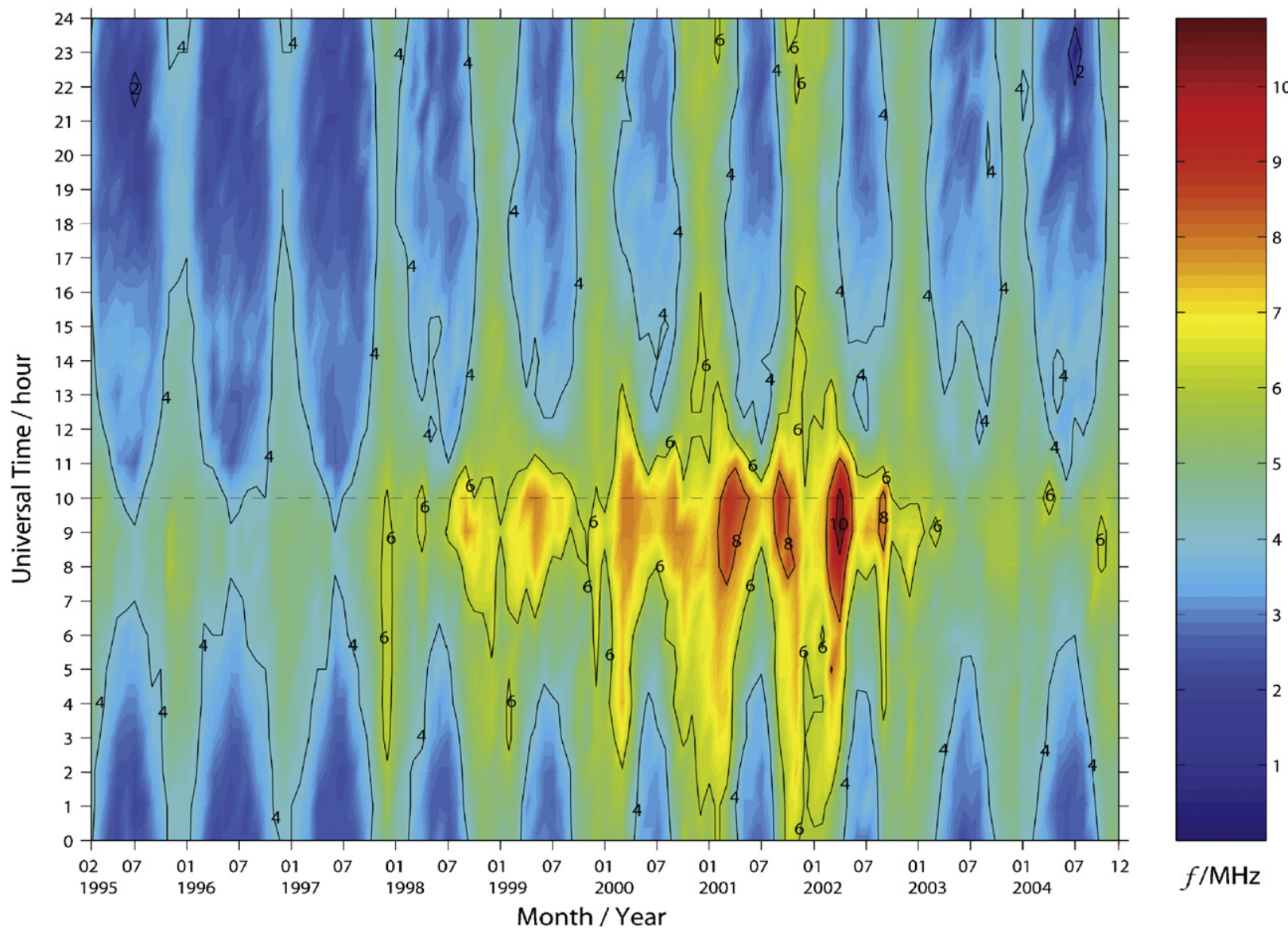

Fig. 5. Mean properties of high-latitude ionosphere variation of foF2 at Zhongshan Station. 
During substorm events energetic electrons are injected into the inner magnetosphere, these then drift eastward under gradient-curvature drift and are precipitated by pitch angle scattering. This increased ionization is frequently seen in a longitudinal belt between $60^{\circ}$ and $70^{\circ}$ geomagnetic latitude at any time, with a maximum occurrence between 8 and 10MLT (Kavanagh et al., 2004a and references therein). Statistical studies of the occurrence of CNA show that it relies on IMF and solar wind conditions.

On the nightside electron density enhancements in the lower ionosphere are directly linked to substorm activity and certain features can be used as a footprint of the region of the electron injection region (Spanswick et al., 2007). Routine monitoring of this process will aid in diagnosing the underlying processes of the substorm. The relationship between CNA and auroral displays has been long established (Hargreaves, 1970) and work continues to try and understand the strong absorption spikes that occur at substorm onset (Aminaei et al., 2006). Typically, substorm expansions comprise multiple intensifications of aurora, producing westward traveling surges (WTS), which in fact are successive surges that form progressively further to the west. These events have been observed at SANAE IV (Wilson and Stoker, 2002), and more detailed studies of the morphology and altitude dependence of these events are planned for the next several years. Although imaging riometers only provide 2-D maps of CNA, when riometers overlap it is possible to extract height information (Terkildsen et al., 2004). A number of pairs of stations exist that are capable of this and it is intended to determine height profiles for absorption features over the IPY period.

Electron density enhancements in the lower ionosphere are also affected by the prevailing local convection pattern. The apparent motion of absorption is not wholly consistent with gradient-curvature drift (Hargreaves and Berry, 1976; Hargreaves and Devlin, 1990). Kikuchi et al. (1990) linked the motion to the interaction of the hot drifting electrons with a cold plasma cloud moving with the convection speed, the latter acting as the trigger for precipitation. Later observations by Kavanagh et al. (2002) and Makarevitch et al. (2004) confirmed that at times the CNA moves with the local ionospheric convection as determined by HF and VHF radars. Thus, local changes in D-region density are highly variable and dependent on prevailing magnetospheric conditions, which have implications for the coupling to the neutral atmosphere. The occurrence of absorption can also be used as an indicator of changes in conductance in the ionosphere (Senior et al., 2007). Thus GLORIA, in connection with other instruments, can be used to study current systems both on a global and very local scale.

The analysis of sudden phase anomalies (SPAs) detected at VLF signals, which are produced by X-ray emission during solar flares, have shown that the low D-region does depend on the solar cycle phase. Recent results (McRae and Thomson, 2004; Pacini and Raulin, 2006, p. 546; Raulin et al., 2006) have shown that the D-region is more sensitive during periods of low solar activity, when the ionospheric reference height is about
$1 \mathrm{~km}$ higher. This can be seen in Fig. 6, which shows the relation between ionospheric reference height lowering, obtained from VLF phase advance, and corresponding $\mathrm{X}$-ray flux of the chosen events during maximum and minimum periods of solar cycle.

Long-term VLF soundings can also be used to probe Lyman-alpha solar emission, especially during quiet solar periods when the D-region below $80 \mathrm{~km}$ is basically formed by this radiation, which ionizes the nitric oxide (NO) molecules (Nicolet and Aikin, 1960).

High-energy solar protons driven by large CMEs and/or solar flares can produce dramatic absorption in the polar and auroral zones (Reid, 1974). Termed polar cap absorption (PCA), the MeV energy protons penetrate to very low altitudes disrupting HF radar and sounder data and with potential for changing the ion chemistry through excess production of $\mathrm{NO}_{x}$ (Seppälä et al., 2007). PCA is most intense in daylight where photo-dissociation keeps the electron density high. In darkness, the CNA decreases as electrons attach to neutrals to form negative ions, thus affecting the chemistry in that region of the ionosphere. Observations using EISCAT have been useful in determining the important chemical species (Collis and Rietveld, 1990), which seems to be $\mathrm{NO}_{3}^{-}$. Another important aspect of these events is the blanket coverage. Absorption tends to be uniform over the polar caps and well into the auroral zones. At the edges of the PCA there is a drop off in absorption that is linked to the ability of energetic protons to penetrate through closed geomagnetic field lines. Although this can be monitored by polar-orbiting satellites, they are incapable of looking at rapid changes in the cut-off boundary. Chains of riometers and imaging riometers provide a method for doing this on local scales. Potemra (1972) demonstrated that the riometer absorption is related to the flux of protons $>10 \mathrm{MeV}$ and Kavanagh et al. (2004b) applied this to an imaging riometer and demonstrated that solar radio emission, though a problem at these times, is not significant enough to disrupt the reliability of the relationship. Clilverd et al. (2007) and Rodger et al. (2006) have used an imaging riometer close to the cutoff boundary to test cut-off models and found good agreement. The implementation of an ion chemistry model allowed the authors to estimate the relationship between PCA and proton flux during nighttime conditions.

\subsection{Magnetospheric particle transport}

Features in the ionosphere are often intrinsically linked to processes occurring in the magnetosphere and this is true of energetic electron precipitation during substorm events. Just as measuring flows in the ionosphere gives us insight into magnetospheric convection, measuring electron density changes in the lower ionosphere (e.g. D-region) allows us to remote-sense magnetospheric particle dynamics. Using ground-based techniques in conjunction with in-situ measurements provide a powerful method for diagnosing space weather events. Riometers and particle flux instruments onboard geostationary 


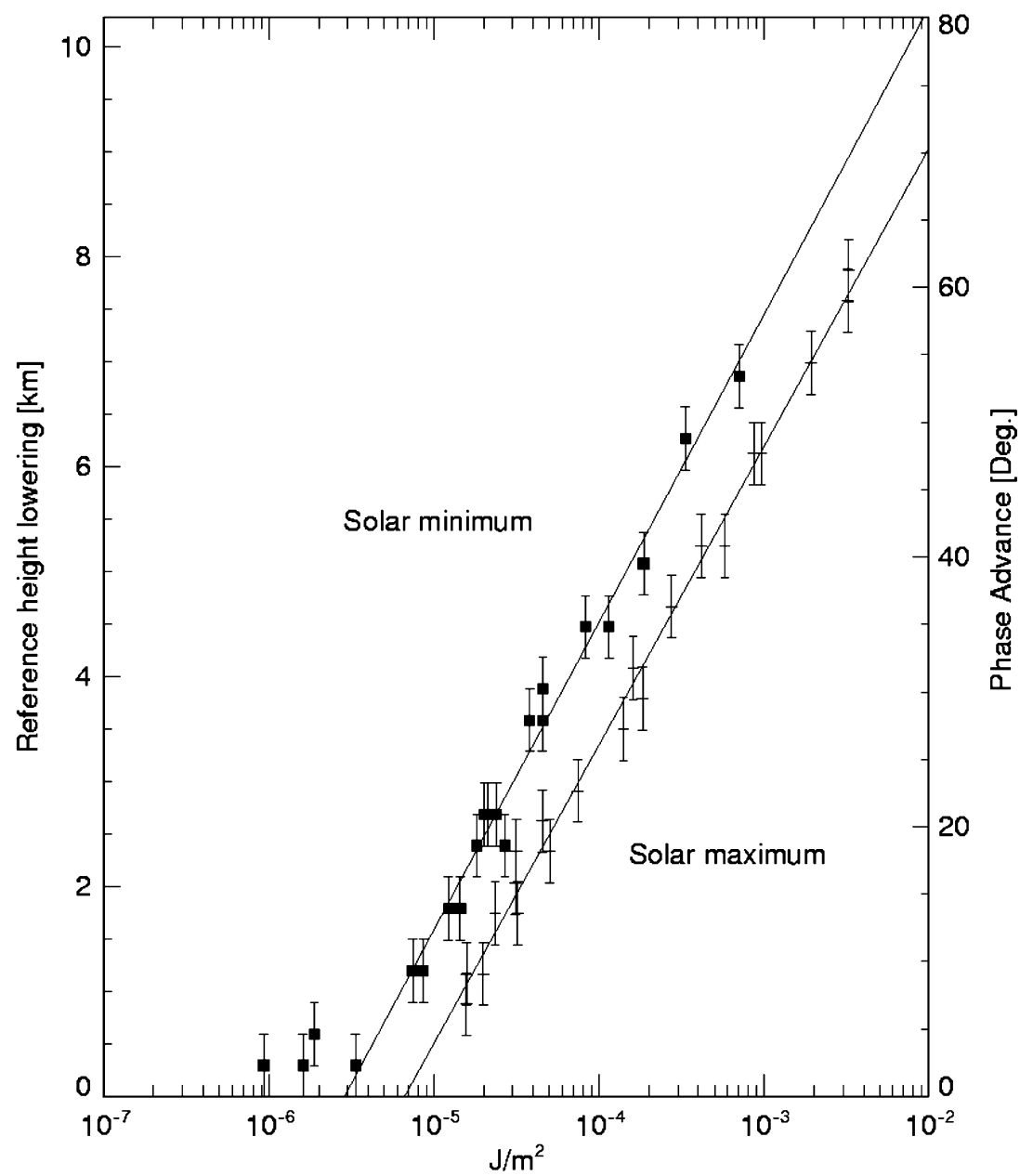

Fig. 6. Relation between ionospheric reference height lowering (VLF phase advance) and the X-ray events flux for solar maximum (squares) and solar minimum (Pacini and Raulin, 2006).

satellites form such a pair for monitoring near-Earth particle injections at substorm onsets (Spanswick et al., 2007). The study of Kavanagh et al. (2007) uses efficiently unified riometer and geostationary particle observations to investigate the development of energetic electron precipitation during so-called sawtooth events. Chains of riometers in Canada and Northern Europe provided observations of energetic electron precipitation whilst six Los Alamos National Laboratory (LANL) satellites provided measurements, distributed in longitude, of the in-situ particle fluxes at geostationary orbit. Two GOES satellites provided additional information regarding the orientation of the magnetic field throughout the sawtooth event; dipolarizations of the magnetic field acting as proxies for the signature of particle injections. For several of the 'teeth' the riometers provided simultaneous measurements of electron precipitation in the nightside (within the footprint of the injection region) and the dawn-noon sector (where gradient-curvature drifting electrons reach peak precipitation). This allowed the large-scale morphology of the precipitation (both azimuthal and latitudinal motions) to be compared and contrasted with the wellestablished patterns for substorm injections. With this wealth of space and ground-based diagnostics Kavanagh et al. (2007) determined that, although periodic in nature and with dispersionless electron injections that covered large regions of local time, each of the 'teeth' in a sawtooth event had precipitation characteristics of 'standard' substorm injections. Another key finding emerged from the closer spacing of the riometers on the ground than the satellites in orbit. Estimates of the apparent motion of absorption in the D-layer (corresponding to motion of the precipitating electrons in the magnetosphere) showed an increase in azimuthal drift speed inferred from the riometer chains, suggestive of energization of the injected particles as they gradient-curvature drift eastward. Conclusions about the energization of injected particles and about the differences and similarities between sawtooth events and standard subtorm injections rely heavily on the improved longitudinal coverage that the ground-based and space-based platforms provide together. 


\subsection{Auroral influence on scintillation}

GPS-signal fading events due to ionospheric scintillation have tendency to occur at auroral and equatorial regions. The occurrence rates at equatorial latitudes show clear dependency on the solar cycle being more frequent around the solar maximum years (Basu et al., 1988). Auroral fading events have been observed especially during geomagnetic storms as well (Mitchell et al., 2005). Such periods are typically accompanied by highly variable auroral displays, which complicates the search of any correspondence between individual auroral structures and scintillation events. Around the time of the scintillation event analysed by Smith et al (2008) the local $\mathrm{AE}$-index values varied in the range of 1000-3000 nT and riometer data showed signal absorption at D-layer altitudes implying significant amounts of energetic particle precipitation. The short but very intensive fading event was observed by three closely located high-frequency GPS-receivers. The appearance of the fading in the GPSdata gives the impression of a moving ionospheric structure causing the disturbances. Simultaneous all-sky camera data show an eastward moving auroral structure in the GPS signal path area. The velocity estimates from GPS and ASC data have best consistency with each other if the altitude of the moving structure is assumed to be around $110 \mathrm{~km}$. Green auroras typically appear at this altitude range, which gives some evidence for a direct link between the visual auroral structures and GPS fading events. The event of Smith et al. was not detectable in the standard 1-min scintillation index as it lasted only for about $10 \mathrm{~s}$. Due to its high intensity this event was anyhow able to cause the GPS receivers to loose lock while trying to catch transmission from a low elevation satellite. This finding leads the authors to suggest systematic monitoring of short duration scintillation events with fastsampled receivers at auroral regions. Although missing one satellite does not harm the GPS navigation performance in nominal conditions the possibly high occurrence rates of short duration fadings can be a significant nuisance in limited sky-view situations.

\subsection{Atmosphere-magnetosphere coupling via lightening}

Lightning activity during strong thunderstorms is known to launch electromagnetic waves that propagate both in the wave guide between the Earth surface and ionosphere (spherics) and along geomagnetic field lines (whistlers). The waves propagating along the field-aligned ducts can interact with radiation belt electrons and under certain conditions cause their precipitation into the atmosphere. The coupling between lightnings, spherics, whistlers and energetic electron precipitation has been addressed with models (Inan et al., 1989) but clear observational evidence covering the whole chain from the troposphere to the near-Earth space has been missing so far. The study of Inan et al. (2007) uses combined observations from VLF-antennas, a lightning detection system, and the DEMETER satellite to inspect lightninginduced electron precipitation (LEP). DEMETER carries advanced instrumentation (with high sensitivity and time resolution) for detecting both electromagnetic waves and weak fluxes of energetic electrons simultaneously. Inan et al. conducted a survey of the DEMETER burst mode data from the summer 2005, which resulted in a data set of $\sim 20$ LEP events. The clearest events together with simultaneous ground-based observations were used to test theoretical models connecting the intensity of electromagnetic waves with the corresponding precipitation fluxes. The data set contains also first in-situ observations of large and relatively persistent regions of enhanced background precipitation, which were generated and maintained by intensive lightning activity within a localized thunderstorm region. The model tested by Inan et al. (Bortnik et al., 2006) uses as inputs the location, time and peak current intensity of a lightning and yields as outputs the energy and number fluxes of the expected electron precipitation. The characteristics of the trapped electron population in the radiation belt are estimated with the model by Vette (1991). The model predicts the LEP burst location to be slightly poleward of the lightning location, which is consistent with the DEMETER observations and with previous observations. Also the time delay between the onsets of the lightning and the electron burst $(<1 \mathrm{~s})$ is similar in the model and in the observations. In energy and number fluxes, the model yields some differences from the observations, but in general, however, both model and measurements show that electrons in the range of $\sim 100-300 \mathrm{keV}$ are the most important contributors in the LEP fluxes. The authors conclude that for future studies to improve the modeled flux estimates better knowledge about the magnetospheric electron populations would be necessary.

\section{Expectations for the IPY}

The IPY encourages a closer contact between different communities and associated facilities; this provides new opportunities to study ionospheric processes at auroral and polar latitudes. ICSU and WMO, who are hosting the IPY campaign, encourage participants to pay special attention to the legacy of their activites. Data during IPY must be carefully collected, freely accessible and adequately preserved; comprehensive metadata must accompany the data and stored in a reliable archive. Thus, the benefits of the IPY can be shared amongst the communities for years to come.

The instrument networks that operate in the northern polar region have traditionally wider user communities than Antarctic instrumentation. During the IPY the ICESTAR programme has shifted the focus towards an interhemispheric approach. Differences in underlying neutral atmospheres as well as internal magnetic field topology and strength are just some examples of issues that ICESTAR addresses and that are important in geospace studies. With increasing amounts of versatile Antarctic observations it has become clear to the research community that complete understanding of the SunEarth link can be achieved only by inspecting interhemispheric polar data sets. The Sun-Earth Interactions 
segment in the Antarctic Master Directory maintained by NASA serves as an important contact point for Antarctic observations and their metadata. When building data archives ICESTAR is active over different fronts and collaborates also with other scientific communities. This is the case of the cooperation with the IPY POLENET project (www.POLENET.org) in which the huge network of GPS receivers managed by POLENET can become of great interest for testing ionospheric imaging over Antarctica.

According to its mission statement the IHY programme (http://ihy2007.org/) incorporates the drivers of geophysical change with large-scale heliospherical processes. The STEREO mission is one example of an IHY project that demonstrates the goals of attempting to understand the processes in our solar system on a system-wide, interconnected scale. The two satellites of STEREO will, for the first time, be able to image on global scales the interaction of the Earth's magnetosphere with different solar wind structures, like coronal mass ejections and shock fronts. Other IHY activities include the Whole Heliosphere Interval campaigns; these last over the whole Carrington rotation period and address the $3 \mathrm{D}$ structure of the heliosphere combining modelling with multiple spacebased and ground-based observations including harmonized data sets from several ionospheric stations.

Besides the scientific heritage, the ionospheric community can also contribute to the assessment of a series of applications addressed to GPS, GLONASS and (in the near future) GALILEO signal corruption, not only in terms of scientific consultancy, but also as an active part of ad hoc task groups working in synergy with private companies and industry. The concept of Virtual Observatories, which IPY recommends for seamless dissemination of scientific data could be useful also in commercial projects once appropriate agreements securing adequate profit for the data providers have been negotiated. Internet-based services distributing near-real-time alerts and other refined data products become gradually more important as we approach more active times within the solar cycle.

Interhemispheric relationships and bi-directional thermosphere-ionosphere linkages present new frontiers of solar-terrestrial science at high latitudes. This paper only partially and briefly describes the activities and background of the ICESTAR/IHY-led Cluster 63 of the IPY, the potential exists to achieve results in terms of special campaigns, interpretation of new results and discussions among the different members. The IPY is an opportunity to bring many scientific communities together. Much of the work on the ionosphere and related topics, requires a multi-instrument approach that is facilitated by the IPY structure and it has relevance to other areas within the IPY portfolio such that multi-disciplinary studies will become important in this period.

\section{Acknowledgements}

L.A. thanks Italian National Program for Antarctic Research (PNRA) and National Research Council (CNR) for supporting the Italian activities at polar latitudes. E.C. thanks Brazilian Antarctic Program (PROANTAR/MMA) and CNPq (Brazilian National Council for Scientific Development and Technology) for supporting the Brazilian activities at polar regions.

P.C. acknowledges the support of South African National Antarctic Programme (SANAP) for South African participation in IPY activities in Antarctica and Marion Island and the contributions of Dr. Andrew Collier and Prof. Pieter Stoker on VLF and riometer observations, respectively.

C.N.M. thanks the UK EPSRC and STFC.

\section{References}

Alfonsi, L., De Franceschi, G., Perrone, L., 2001. Long term trend in the high latitude ionosphere. Physics and Chemistry of the Earth 26 (5), 303-307.

Alfonsi, L., De Franceschi, G., Perrone, L., Materassi, M., 2002. Long term trends of the critical frequency of the F2 layer at northern and southern high latitude regions. Physics and Chemistry of the Earth 27 (6-8), 607-612.

Aminaei, A., Honary, F., Kavanagh, A.J., Spanswick, E., Viljanen, A., 2006. Characteristics of night-time absorption spike events. Annales Geophysicae 24, 1887-1904.

Basu, S., MacKenzie, E., Basu, S., 1988. Ionospheric constraints on UHF/VHF communications links during solar maximum and minimum periods. Radio Science 23, 363-378.

Bortnik, J., Inan, U.S., Bell, T.F., 2006. Temporal signatures of radiation belt electron precipitation induced by lightning-generated MR whistler waves: 1. Methodology. Journal of Geophysical Research 111, A02204.

Bremer, J., 1992. Ionospheric trends in mid-latitudes as a possible indicator of the atmospheric greenhouse effect. Journal of Atmospheric and Terrestrial Physics 54, 1505-1511.

Bust, G.S., Mitchell, C.N., 2008. The history, current state and future directions of ionospheric imaging. Reviews of Geophysics 46 RG1003.

Chisham, G., Lester, M., Milan, S.E., Freeman, M.P., Bristow, W.A., Grocott, A., MacWilliams, K.A., Ruohoniemi, J.M., Yeoman, T.K., Dyson, P. Greenwald, R.A., Kikuchi, T., Pinnock, M., Rash, J., Sato, N., Sofko, G. Villain, J.-P., Walker, A.D.M., 2007. A decade of the Super Dual Auroral Radar Network (SuperDARN): scientific achievements, new techniques and future directions. Surveys in Geophysics 28, 33-109.

Cilliers, P.J., Mitchell, C.N., Opperman, B.D.L., 2006. Characterization of the ionosphere over the South Atlantic Ocean by means of ionospheric tomography using dual frequency GPS signals received on board a research ship. In: Proceedings of Specialists' Meeting RTOMP-IST-056 on "Characterising the Ionosphere," Organised by the NATO Information Systems Technology (IST) Panel in Conjunction with U.R.S.I., University of Alaska Fairbanks, Alaska, USA, 12-16 June 2006.

Clilverd, M.A., Rodger, C.J., Moffat-Griffin, T., Verronen, P.T., 2007. Improved dynamic geomagnetic rigidity cutoff modeling: testing predictive accuracy. Journal of Geophysical Research 112 A08302.

Coco, I., Amata, E., Alfonsi, L., De Franceschi, G., Marcucci, M.F., Romano V., Lester, M., Dyson, P., 2007. Statistical correlations between GPS scintillations and SuperDARN HF backscatter. IUGG XXIV General Assembly, 2-13 July 2007.

Collis, P.N., Rietveld, M.T., 1990. Mesospheric observations with the EISCAT UHF radar during polar cap absorption events: 1. Electron densities and negative ions. Annales Geophysicae 8, 809-824.

De Franceschi, G., Alfonsi, L., Romano, V., 2006. ISACCO: an Italian project to monitor the high latitudes ionosphere by means of GPS receivers, "Eye on ionosphere". GPS Solutions, doi:10.1007/s10291-006-0036-6.

De Franceschi, G., Alfonsi, L., Romano, V., Aquino, M., Dodson, A Mitchell, C.N., Wernik, A.W., 2008. Dynamics of high latitude patches and associated small scale irregularities. Journal of Atmospheric and Solar-Terrestrial Physics 70, 879-888.

Detrick, D.L., Rosenberg, T.J., 1990. A phased-array radiowave imager for studies of cosmic noise absorption. Radio Science 25 (4), 325.

Dungey, J.W., 1961. Interplanetary magnetic field and the auroral zones. Physical Review Letters 6, 47.

Greenwald, R.A., Baker, K.B., Dudeney, J.R., Pinnock, M., Jones, T.B., Thomas, E.C., Villain, J.P., Cerisier, J.-C., Senior, C., Hanuise, C., Hunsucker, R.D., Sofko, G., Koehler, J., Nielsen, E., Pellinen, R., Walker A.D.M., Sato, N., Yamagishi, H., 1995. DARN/SUPERDARN: a global 
view of the dynamics of high-latitude convection. Space Science Review 71, 761-796.

Hagfors, T., Grill, M., Honary, F., 2003. Performance comparison of cross correlation and filled aperture imaging riometers. Radio Science 38 (6), 1109.

Haines, D.M., Reinisch, B.W., 1995. Digisonde Portable Sounder System Manual. University of Massachusetts Lowell Center for Atmospheric Research.

Hargreaves, J.K., 1969. Auroral Absorption of HF radio waves in the ionosphere: a review of results from the first decade of riometry. Proceedings of the IEEE 57, 1348-1373.

Hargreaves, J.K., 1970. Conjugate and closely-spaced observations of auroral radio absorption-IV. The movement of simple features. Planetary Space Science 18, 1691-1705.

Hargreaves, J.K., Berry, M.G., 1976. The eastward movement of the structure of auroral radio absorption events in the morning sector. Annales Geophysicae 32, 401-406.

Hargreaves, J.K., Devlin, T., 1990. Morning Sector electron precipitation events observed by incoherent scatter radar. Journal of Atmospheric and Terrestrial Physics 52, 193-203.

Helliwell, R.A., Katsufrakis, J.P., Trimpi, M.L., 1973. Whistler-induced amplitude perturbation in VLF propagation. Journal of Geophysical Research 78, 4679-4688.

Heppner, J.P., Maynard, N.C., 1987. Empirical high-latitude electric field models. Journal of Geophysical Research 92, 4467-4489.

Imber, S.M., Milan, S.E., Hubert, B., 2006. The auroral and ionospheric flow signatures of dual lobe reconnection. Annales Geophysicae 24, 3115-3129.

Imber, S.M., Milan, S.E., Hubert, B., 2007. Observations of significant flux closure by dual lobe reconnection. Annales Geophysicae 25, 1617-1627.

Inan, U.S., Bell, T.F., Chang, H.C., 1982. Particle precipitation induced by short-duration VLF waves in the magnetosphere. Journal of Geophysical Research 87, 6243-6264.

Inan, U.S., Walt, M., Voss, H., Imholt, W., 1989. Energy spectra and pitch angle distribution of lightning-induced electron precipitation: analysis of an event observed on the S81-1 (SEEP) satellite. Journal of Geophysical Research 94, 1379-1401.

Inan, U.S., Piddyachiy, D., Peter, W.B., Sauvaud, J.A., Parrot, M., 2007. DEMETER satellite observations of lightning-induced electron precipitation. Geophysical Research Letters.

Jakowski, N., Sardon, E., Engler, E., Jungstand, A., Klähn, D., 1996. Relationships between GPS-signal propagation errors and EISCAT observations. Annales Geophysicae 14, 1429-1436.

Jarvis, M.J., 2001. Antarctica's role in understanding long term change in the upper atmosphere. Surveys in Geophysics 22, 155-174.

Kamide, Y., Richmond, A.D., Emery, B.A., Hutchins, C.F., Ahn, B.H., de la Beaujardiere, O., Foster, J.C., Heelis, R.A., Kroehl, H.W., Rich, F.J., Slavin, J.A., 1994. Groundbased studies of ionospheric convection associated with substorm expansion. Journal of Geophysical Research 99, 19451-19466.

Kavanagh, A.J., Honary, F., McCrea, I.W., Donovan, E., Woodfield, E.E., Manninen, J., Anderson, P.C., 2002. Substorm related changes in precipitation in the dayside auroral zone-a multi instrument case study. Annales Geophysicae 20, 1321-1334.

Kavanagh, A.J., Kosch, M., Honary, F., Senior, A., Marple, S.R., Woodfield, E.E., McCrea, I.W., 2004a. The statistical dependence of auroral absorption on geomagnetic and solar wind parameters. Annales Geophysicae 22, 877-887.

Kavanagh, A.J., Marple, S.R., Honary, F., McCrea, I.W., Senior, A., 2004b. On solar protons and polar cap absorption: constraints on an empirical relationship. Annales Geophysicae 22 (4), 1133-1147.

Kavanagh, A.J., Lu, G., Donovan, E.F., Reeves, G.D., Honary, F., Manninen, J., Immel, T.J., 2007. Energetic electron precipitation during sawtooth injections. Annales Geophysicae 25, 1199-1214.

Kelly, T., 1981. Preliminary Instructions for Turning on, Setting up, and Initial Testing of IPS-42 Ionosonde. KEL Aerospace Pty. Ltd., Australia.

Kersley, L., Pryse, S.E., Wheadon, N.S., 1988. Small scale ionospheric irregularities near regions of soft particle precipitation-scintillation and EISCAT observations. Journal of Atmospheric and Terrestria Physics 50, 1047-1055.

Kikuchi, T., Yamagishi, H., Lester, M., 1990. Drift of auroral absorption due to the magnetospheric convection observed with the scanning narrow beam riometer during SUNDIAL-86. Annales Geophysicae 8 (6), 431-440.

Laštovicka, J., 2005. On the role of solar and geomagnetic activity in longterm trends in the atmosphere-ionosphere system. Journal of Atmospheric and Solar-Terrestrial Physics 67, 83-92.

Lastovicka, J., Mikhailov, A.V., Ulich, Th., Bremer, J., Elias, A.G., Ortiz de Adler, N., Jara, V., Abarca del Rio, R., Foppiano, A.J., Ovalle, E., Danilov,
A.D., 2006. Long-term trends in foF2: a comparison of various methods. Journal of Atmospheric and Solar-Terrestrial Physics 68 (17), 1854-1870.

Lilensten, J., Cander, Lj.R., 2003. Calibration of the TEC derived from GPS measurements and from ionospheric models using the EISCAT data. Journal of Atmospheric and Solar-Terrestrial Physics 65, 833-842.

Little, C.G., Leinbach, H., 1959. The riometer: a device for the continuous measurements of ionospheric absorption. Proceedings of IRE 37, 315-320.

Liu, R., 1998. Present and future research program in solar-terrestrial physics at Zhongshan Station, Antarctica. In: Xu, R.L., Lui, A.T.Y. (Eds.), Magnetospheric Research with Advanced Techniques. Elsevier Science, Amsterdam.

Liu, R., Zhu, Y., 1999. Ionospheric drift properties and its response the IMF conditions at Zhongshan Station, Antarctica. Chinese Journal of Geophysics 42 (1), 13-24.

Luntama, J.-P., Mitchell, C.N., Spencer, P., 2007. Mesoscale ionospheric tomography over Finland. Fourth European Space Weather Week, 5-9 November 2007, Brussels, Belgium. Available at <http:// sidc.oma.be/esww4/>.

MacDougall, J.W., 1997. Canadian Advanced Digital Ionosonde Users Manual. University of Western Ontario, Scientific Instrumentation Ltd.

Makarevitch, R.A., Honary, F., McCrea, I.W., Howells, V.S.C., 2004. Imaging riometer observations of drifting absorption patches in the morning sector. Annales Geophysicae 22 (10), 3461-3478.

Marcucci, M.F., Coco, I., Ambrosino, D., Amata, E., Milan, S.E., Bavassano Cattaneo, M.B., Retinò, A., 2008. Extended SuperDARN and IMAGE observations for northward IMF: evidence for dual lobe reconnection, Journal of Geophysical Research, in press.

McRae, W.M., Thomson, N.R., 2004. Solar flare induced ionospheric Dregion enhancements from VLF phase and amplitude observations. Journal of Atmospheric and Terrestrial Physics 66, 77-87.

Mendillo, M., Klobuchar, A., 2006. Total electron content: synthesis of past storm studies and needed future work. Radio Science 41, RS5S02.

Mitchell, C.N., Spencer, P.S.J., 2003. A three-dimensional time-dependent algorithm for ionospheric imaging using GPS. Annals of Geophysics 46 (4), 687-696.

Mitchell, C.N., Alfonsi, L., De Franceschi, G., Lester, M., Romano, V. Wernik, A.W., 2005. GPS TEC and scintillation measurements from the polar ionosphere during the October 2003 storm. Geophysical Research Letters 32 (12), L12S03.

Morris, R.J., Monselesan, D.P., Hyde, M.R., Breed, A.M., Wilkinson, P.J., Parkinson, M.L., 2003. Southern polar cap DPS and CADI ionosonde measurements: 1. Ionogram comparison. Advances in Space Research 33 (6), 923-929.

Nicolet, M., Aikin, A., 1960. The formation of the D region of the ionosphere. Journal of Geophysical Research 65, 1469-1483.

Pacini, A.A., Raulin, J.-P., 2006. Solar X-ray flares and ionospheric sudden phase anomalies relationship: a solar cycle phase dependence. Journal of Geophysical Research 111, A09301.

Papitashvili, V.O., Belov, B.A., Faermark, D.S., Feldstein, Y.I., Golyshev, S.A., Gromova, L.I., Levitin, A.E., 1994. Electric-potential patterns in the northern and southern polar-regions paramaterized by the interplanetary magnetic field. Journal of Geophysical Research 99, 13251-13262.

Peter, W.B., Inan, U.S., 2004. On the occurrence and spatial extent of electron precipitation induced by oblique nonducted whistler waves. Journal of Geophysical Research 109, A12215.

Piggott, W.R., Rawer, K., 1972. U.R.S.I. Handbook of Ionogram Interpretation and Reduction, World Data Center A for Solar-Terrestrial Physics. NOAA, Boulder, CO.

Pirog, O.M., Zherebtsov, G.A., Dolgoarshinnikh, B.G., 1987. Dynamics of ionospheric disturbances at high latitudes. Acta Geodetica et Geophysica Hungarica 22, 87-95.

Pirog, O.M., Polekh, N.M., Zherebtsov, G.A., et al., 2006. Seasonal variations of the ionospheric effects of geomagnetic storms at different latitudes of East Asia. Advances in Space Research 37 (5), 1075-1080.

Pirog, O.M., Polekh, N.M., Tashchilin, A.V., Romanova, E.B., 2007. Density gradients at evening ionospheric troughs in the East sector. Proceedings of SPIE V 6936, 346-356 http://spiedl.org.

Potemra, T.A., 1972. The empirical connection of riometer absorption to solar protons during PCA events. Radio Science 7, 571-577.

Raulin, J.-P., Abe Pacini, A., Kaufmann, P., Correia, E., Aparecida, G. Martinez, M., 2006. On the detectability of solar X-ray flares using very low frequency sudden phase anomalies. Journal of Atmospheric and Terrestrial Physics 68, 1029-1035. 
Reid, G.C., 1974. Polar-cap absorption-observation and theory. Fundamentals of Cosmic Physics 1, 167-202.

Rodger, C.J., Clilverd, M.A., Verronen, P.T., Ulich, T., Jarvis, M.J., Turunen, E. 2006. Dynamic geomagnetic rigidity cutoff variations during a solar proton event. Journal of Geophysical Research 111, A04222.

Romano, V., Zuccheretti, E., De Franceschi, G., Pezzopane, M., Alfonsi, L., Tutone, G., Doumaz, F., 2004. Ionospheric observatory development at Mario Zucchelli station. INAG Bulletin 65.

Romano, V., Pau, S., Pezzopane, M., Zuccheretti, E., Zolesi, B., De Franceschi, G., Locatelli, S., 2008. The electronic Space Weather upper atmosphere (eSWua) project at INGV: advancements and state of the art. Annales Geophysicae 26, 345-351.

Romanova, E.B., Tashchilin, A.V., Zherebtsov, G.A., et al., 2006. Modeling of the seasonal effects of geomagnetic storms in the Eastern Asia ionosphere. International Journal of Geomagnetism and Aeronomy 6 . GI3003.

Rosenberg, T.J., Detrick, D.L., Venkatesan, D., van Bavel, G., 1991. A comparative study of imaging and broad-beam riometer measurements: The effect of spatial structure on the frequency dependence of auroral absorption. Journal of Geophysical Research 96, 17793-17803.

Rosenberg, T.J., Wang, Z., Rodger, A.S., Dudeney, J.R., Baker, K.B., 1993. Imaging riometer and $\mathrm{HF}$ radar measurements of drifting $\mathrm{F}$ region electron density structures in the polar cap. Journal of Geophysical Research 98, 7757-7764.

Ruohoniemi, J.M., Baker, K.B., 1998. Large-scale imaging of high-latitude convection with Super Dual Auroral Radar Network HF radar observations. Journal of Geophysical Research 103, 20797-20811.

Ruohoniemi, J.M., Greenwald, R.A., 1996. Statistical patterns of highlatitude convection obtained from Goose Bay HF radar observations. Journal of Geophysical Research 101, 21743-21763.

Ruohoniemi, J.M., Greenwald, R.A., 2005. Dependencies of high-latitude plasma convection: consideration of interplanetary magnetic field, seasonal, and universal time factors in statistical patterns. Journal of Geophysical Research 110, A09204.

Senior, A., Kavanagh, A.J., Kosch, M.J., Honary, F., 2007. Statistical relationships between cosmic radio noise absorption and ionospheric electrical conductances in the auroral zone. Journal of Geophysical Research 112, A11301.

Seppälä, A., Clilverd, M.A., Rodger, C.J., 2007. NOx enhancements in the middle atmosphere during 2003-2004 polar winter: relative significance of solar proton events and the aurora as a source. Journal of Geophysical Research 112, D23303.

Shpynev, B.G., 2003. Incoherent scatter Faraday rotation measurements on a radar with single linear polarization. Radio Science 39, RS3001.

Skone, S., Hoyle, V., 2005. Canadian GPS NETWORK for ionosphere monitoring (CANGIM). GPS Solutions 9, 59-62.

Smith, A.M., Mitchell, C.A., Watson, R.J., Meggs, R.W., Kintner, P.M., Kauristie, K., Honary, F., 2008. GPS scintillation in the high arctic associated with an auroral arc. Space Weather 6, S03D01.

Spanswick, E., Donovan, E., Friedel, R., Korth, A., 2007. Ground based identification of dispersionless electron injections. Geophysical Research Letters 34, L03101.

Stauning, P., 1984. Absorption of cosmic noise in the E-region during electron heating events. A new class of riometer absorption events. Geophysical Research Letters 11, 1184-1187.
Stauning, P., 1994. Coupling of IMF BY variations into the polar ionospheres through interplanetary field-aligned currents, J. Geophysical Research Letters 99, 17,309-17,322.

Stauning, P., Olsen, J.K., 1989. Observations of the unstable plasma in the disturbed polar E-region. Physica Scripta 40, 325-332.

Stolle, C., Jakowski, N., Schlegel, K., Rietveld, M., 2004. Comparison of high latitude electron density profiles obtained with the GPS radio occultation technique and EISCAT measurements. Annales Geophysicae 22, 2015-2022.

Tashchilin, A.V., Romanova, E.B., 2002. Numerical modeling the highlatitude ionosphere. Proceeding of COSPAR Colloquia Series 14, 315-325.

Terkildsen, M.B., Fraser, B.J., Yamagishi, H., 2004. Determination of the altitudinal peak of Cosmic Noise Absorption using a vertical parallax technique. Geophysical Research Letters 31, L07802.

Ulich, Th., Turunen, E., 1997. Evidence for long-term cooling of the upper atmosphere in ionosonde data. Geophysical Research Letters 24, 1103-1106

Van Dierendonck, A.J., Klobuchar, J., Hua, Q., 1993. Ionospheric scintillation monitoring using commercial single frequency C/A code receivers. In: ION GPS-93 Proceedings: Sixth International Technical Meeting of the Satellite Division of the Institute of Navigation, Institute of Navigation, Salt Lake City, UT, pp. 1333-1342.

Vette, J., 1991. The AE-8 Trapped Electron Model Environment. Report 9124. Natl., Space Sci., Data Cent., Greenbelt, MD.

Wait, J.R., Spies, K., 1964. NBS Technical Note, 300.

Wang, Z., Rosenberg, T., Stauning, P., Basu, S., Crowley, G., 1994 Calculations of riometer absorption associated with $\mathrm{F}$ region plasma structures based on Sondre Stromfjord incoherent scatter radar observations. Radio Science 29 (1), 209-215.

Weimer, D.R., 1995. Models of high-latitude electric potentials derived with a least error fit of spherical harmonic coefficients. Journal of Geophysical Research 100, 19595-19608.

Wernik, A.W., Secan, J.A., Fremouw, E.J., 2003. Ionospheric irregularities and scintillation. Advances in Space Research 31 (4), 971-981.

Wernik, A.W., Alfonsi, L., Materassi, M., 2007. Scintillation modelling using in-situ data. Radio Science 42, RS1002.

Wilson, A., Stoker, P.H., 2002. Imaging riometer observations on energetic electron precipitation at SANAE IV, Antarctica. Journal of Geophysical Research 107 (A10) SMP 2-1-2-10.

Xu, Z.H., Liu, R.Y., Liu, S.L., et al., 2006. Variations of the ionosphere F2 layer critical frequency at Zhongshan Station, Antarctica. Chinese Journal of Geophysics 49 (1), 1-8.

Zherebtsov, G.A., Pirog, O.M., 2001. Studies of longitudinal variations of the ionosphere in the Russian Sector. Advances in Space Research 27, 1391-1394.

Zherebtsov, G., Zavorin, V., Medvedev, V., Nosov, V., Potekhin, P., Shpynev, B.G., 2002. Irkutsk incoherent scatter radar. Journal of Communications Technology and Electronics 47 (11), 1222-1228.

Zherebtsov, G.A., Pirog, O.M., Polekh, N.M., Ratovskii, K.G., Smirnov, V.F., Stepanov, A.E., Shi, J.K., Wang, X., 2005. The ionospheric situation in the Eastern Asian longitudinal sector during the geoactive period October-November 2003. Geomagnetizm and Aeronomy 45, 101-108.

Zuccheretti, E., Tutone, G., Sciacca, U., Bianchi, C., Arokiasamy, B.J., 2003. The new AISINGV digital ionosonde. Annals of Geophysics 46 (4), 647-659. 